\title{
Kilka spostrzeżeń dotyczących genealogii królów izraelskich i judzkich
}

\author{
Paweł M. Mucha \\ Poznań \\ pablomarco@wp.pl (Dhtps://orcid.org/0000-0001-9926-6623
}

Niedawno na łamach „Ruchu Biblijnego i Liturgicznego” ukazał się mój artykuł podważający wiarygodność genealogii królów izraelskich i judzkich oraz uznający ją za wynik redakcji tekstu biblijnego ${ }^{1}$. Tym samym zakwestionowane zostały wyniki badań wielu uczonych, którzy podejmowali się trudu ustalenia dokładnych dat panowania władców obu królestw² ${ }^{2}$.

1 P. M. Mucha, Przyczynek do chronologii królów Izraela i Judy, „Ruch Biblijny i Liturgiczny” 72 (2019) nr 2, s. 131-148, https://doi.org/10.21906/rbl.3629.

2 Zob. J. Lewy, Die Chronologie der Könige von Israel und Juda, Gießen 1927, https://doi. org/10.1515/9783111551203; J. Begrich, Die Chronologie der Könige von Israel und Juda. Und die Quellen des Rahmens der Königsbücher, Tübingen 1929 (Beiträge zur Historischen Theologie, 3); S. Mowinckel, Die Chronologie der israelitischen und jüdischen Könige, Leiden 1932 (Acta Orientalia, 10); E. R. Thiele, The Chronology of the Kings of Judah and Israel, ,Journal of Near Eastern Studies” 3 (1944) nr 3, s. 137-186, https://doi. org/10.1086/370716; W. F. Albright, The Chronology of the Divided Monarchy of Israel, „Bulletin of the American Schools of Oriental Research” 100 (1945), s. 16-22, https://doi. org/10.2307/1355182; C. Schedl, Textkritische Bemerkungen Zu Den Synchronismen Der Könige Von Israel Und Juda, „Vetus Testamentum” 12 (1962) nr 1, s. 88-119, https://doi. org/10.1163/156853362X00047; A. Jepsen, R. Hanhart, Untersuchungen zur israelitischjüdischen Chronologie, Berlin 1964 (Beihefte zur Zeitschrift für die alttestamentliche Wissenschaft, 88); V. Pavlovský, E. Vogt, Die Jahre der Könige von Juda und Israel, „Biblica” 45 (1964) nr 3, s. 321-347, https://www.jstor.org/stable/42640808; A. Jepsen, Noch Einmal Zur Israelitisch-Jüdischen Chronologie, „Vetus Testamentum” 18 (1968) nr 1-4, s. 31-46, https://doi.org/10.1163/156853368X00032; W. Wifall, The Chronology of the Divided Monarchy of Israel, „Zeitschrift für die Alttestamentliche Wissenschaft” 80 (1968) nr 3, s. 319-337, https://doi.org/10.1515/zatw.1968.80.3.319; K. T. Andersen, Die Chronologie der Könige von Israel und Juda, , Studia Theologica. Nordic Journal of Theology” 23 (1969) nr 1, s. 69-114, https://doi.org/10.1080/00393386908599903; K. T. Andersen, Noch einmal. Die 
Główne spostrzeżenie dotyczy liczby władców w obu państwach. Zarówno w Izraelu, jak i w Judzie (dynastii Dawidowej) było po 22 królów ${ }^{3}$. Jest to o tyle zaskakujące, że tylu było też patriarchów od Adama do Jakuba. Autor greckiej Księgi Rodzaju znał jeszcze Kainama (LXX: Rdz 11, 13; por. Łk 3, 36) ${ }^{4}$. Jednak redaktor hebrajskiej Księgi Rodzaju pominął tego patriarchę . W ten sposób uzyskał liczbę 22 patriarchów. Mógł to być zamierzony cel autora pierwszej księgi biblijnej, ponieważ z tylu liter składa się alfabet hebrajski ${ }^{6}$. W starożytności bowiem liczbom i literom nadawano szczególne znaczenie ${ }^{7}$.

Chronologie der Könige von Israel und Juda, „Scandinavian Journal of the Old Testament” 3 (1989) nr 1, s. 1-45, https://doi.org/10.1080/09018328908584908; W. H. Barnes, Studies in the Chronology of the Divided Monarchy of Israel, Leiden 1991 (Harvard Semitic Monographs, 48), https://doi.org/10.1163/9789004369573; E. R. Thiele, The Mysterious Numbers of the Hebrew Kings, Grand Rapids 1994; G. Galil, The Chronology of the Kings of Israel and Judah, Leiden-New York 1996 (Studies in the History and Culture of the Ancient Near East, 9); T. Brzegowy, Chronologia epoki królewskiej w starożytnym Izraelu, „Ruch Biblijny i Liturgiczny” 51 (1998) nr 4, s. 261-270, https://doi.org/10.21906/rbl.697; M. Christine Tetley, The Reconstructed Chronology of the Divided Kingdom, Winona Lake 2005; G. Larsson, The Chronology of the Kings of Israel and Judah as a System, „Zeitschrift für die Alttestamentliche Wissenschaft” 114 (2006) nr 2, s. 224-235, https://doi.org/10.1515/ zatw.2002.012; J. Hayes, P. Hooker, A New Chronology for the Kings of Israel and Judah and Its Implications for Biblical History and Literature, Eugene 2007; A. Laato, New Viewpoints on the Chronology of the Kings of Judah and Israel, ,Zeitschrift für die Alttestamentliche Wissenschaft” 98 (1986) nr 2, s. 210-221, https://doi.org/10.1515/zatw.1986.98.2.210.

3 Por. J. Hull, King Lists as a Structuring Principle in the Book of Kings, [w:] Partners with God: Theological and Critical Readings of the Bible in Honor of Marvin A. Sweeney, eds. S. L. Birdsong, S. Frolov, t. 2, Claremont 2017, s. 133-146, https://doi.org/10.2307/j. ctvbcd33m.17.

4 Septuaginta. Idest Vetus Testamentum graece iuxta LXX interpretes, edidit A. Rahlfs, Stuttgart 2014; por. H. R. Jacobus, The Curse of Cainan (Jub. 8.1-5): Genealogies in Genesis 5 and Genesis 11 and a Mathematical Pattern, „Journal for the Study of the Pseudepigrapha” 18 (2009) nr 3, s. 207-232, https://doi.org/10.1177/0951820709103182.

5 Biblia Hebraica Stuttgartensia, ed. W. Rudolph, H. P. Rüger et al., wyd. 5, Stuttgart 1997; A. Dotan, Biblia Hebraica Leningradensia, Peabody 2000; A. Tal, Biblia Hebraica Quinta, fascicle 7: Genesis, Stuttgart 2016; por. R. S. Hendel, The Text of Genesis 1-11. Textual Studies and Critical Edition, New York-Oxford 1998, s. 61-80.

6 J. A. Benner, The Ancient Hebrew Language and Alphabet. Understanding the Ancient Hebrew Language of the Bible Based on the Ancient Hebrew Culture and Thought, College Station 2004, s. 119-120.

7 Zob. Zahlen- und Buchstabensysteme im Dienste religiöser Bildung, hrsg. von L. V. Schimmelpfennig, R. G. Kratz, Tübingen 2019 (Studies in Education and Religion 
Taką kompozycją genealogii królów Izraela i Judy autor Ksiąg Samuela i Królewskich odwołał się do epoki patriarchów, przeciwstawiając jednak epokę królewską epoce patriarchów. Jak za pierwszego człowieka Adama nastąpił upadek ludzkości, tak za ostatniego króla izraelskiego Ozeasza nastąpił upadek państwa izraelskiego, a za ostatniego króla judzkiego Sedecjasza nastąpił upadek Judy. Jak trzej ostatni patriarchowie są najważniejsi dla Narodu Wybranego, tak trzej pierwsi królowie Saul, Dawid i Salomon są najważniejsi dla epoki królewskiej starożytnego Izraela. Jak ostatni z patriarchów Jakub daje początek Narodowi Wybranemu (dwunastu pokoleniom), tak Dawid daje początek nowej dynastii, z którą związane są obietnice mesjańskie.

Powyższe spostrzeżenia przemawiają za dalszym badaniem historii władców Izraela i Judy, zwłaszcza że ten wątek nie był jeszcze porusza$n y^{8}$. Jeśli bowiem genealogie królów Izraela i Judy nie odzwierciedlają rzeczywistej sukcesji, lecz są wynikiem kompozycji redaktora biblijnego, to można oczekiwać, że przynajmniej w kilku miejscach, kluczowych dla autora biblijnego, znaleźli się władcy według jego koncepcji, a nie rzeczywistej sukcesji. W genealogii patriarchów szczególne znaczenie mają Henoch oraz Noe. Henoch był siódmym patriarchą, a Noe dziesiątym. Nie ma tutaj mowy o żadnym przypadku. Liczby „siedem” i „dziesięć” mają w Biblii szczególne znaczenie ${ }^{9}$. Liczba siedem oznacza pełnię i doskonałość, co świetnie pasuje do Henocha ${ }^{10}$. Był tak spra-

in Ancient and Pre-Modern History in the Mediterranean and its Environs, 5), https:// doi.org/10.1628/978-3-16-158319-3.

8 Zob. M. Avioz, The Book of Kings in Recent Research (Part I), „Currents in Biblical Research” 4 (2005) nr 1, s. 11-55, https://doi.org/10.1177/1476993X05055585; M. Avioz, The Book of Kings in Recent Research (Part II), „Currents in Biblical Research” 5 (2006) nr 1, s. 11-57, https://doi.org/10.1177/1476993X06068698; R. K. Duke, Recent Research in Chronicles, „Currents in Biblical Research” 8 (2009) nr 1, s. 10-50, https://doi. org/10.1177/1476993X09338966.

9 Zob. częstotliwość i miejsca ich występowania w: J. Flis, Konkordancja Starego i Nowego Testamentu do Biblii Tysiaclecia, wyd. 4, Warszawa 2004 (Prymasowska Seria Biblijna).

10 Na temat szczególnego znaczenia liczby siedem por. G. G. G. Reinhold, Die Zahl Sieben im Alten Orient: Studien zur Zahlensymbolik in der Bibel und ihrer altorientalischen Umwelt. The number seven in the ancient Near East : studies on the numerical symbolism in the Bible and its ancient Near Eastern environment, Frankfurt am Main-Berlin-Bern-BruxellesNew York-Oxford-Wien 2008. 
wiedliwy, że został wyłączony spod ogólnego prawa śmierci (Rdz 5, 24; Syr 44, 16; Syr 49, 14; Hbr 11, 5). Także Noe był sprawiedliwy i uratował rodzaj ludzki w czasie potopu ${ }^{11}$. To od niego pochodzi ludzkość po tym tragicznym wydarzeniu. Stąd jego dziesiąte miejsce w genealogii.

Jeśli redaktor Ksiąg Samuela i Królewskich wzorował epokę królewską starożytnego Izraela na epoce patriarchów, to można oczekiwać, że w genealogiach królów na siódmym i dziesiątym miejscu znaleźli się władcy zgodnie z intencją autora biblijnego, a nie rzeczywistej sukcesji. Skoro jednak epoka królewska jest odwróceniem epoki patriarchów, to należy się przyjrzeć siódmemu i dziesiątemu władcy w obu genealogiach, ale w odwróconej kolejności, czyli należy ich liczyć od końca genealogii. Wystarczy zestawić genealogię patriarchów z genealogiami królów Izraela i Judy w odwróconej kolejności, a otrzymuje się zaskakujący wynik, zgodny z dotychczasowymi przypuszczeniami:

\begin{tabular}{|c|c|c|c|c|}
\hline & & Izrael & Patriarchowie & Dynastia Dawidowa \\
\hline 1 & K & Ozeasz & Adam & Sedecjasz \\
\hline 2 & 1 & Pekach & Set & Jjakin \\
\hline 3 & 1 & Pekachiasz & Enosz & Jojakim \\
\hline 4 & 7 & Menachem & Kenan & Joachaz \\
\hline 5 & 1 & Szallum & Mahalaleel & Jozjasz \\
\hline 6 & 1 & Zachariasz & Jered & Amon \\
\hline 7 & 1 & JEROBOAM II & HENOCH & MANASSES \\
\hline 8 & 7 & Joasz & Matuzalem & Ezechiasz \\
\hline 9 & 0 & Joachaz & Lamech & Achaz \\
\hline 10 & J & JEHU & NOE & JOTAM \\
\hline 11 & 7 & Joram & Sem & Azariasz \\
\hline
\end{tabular}

11 W. Malcolm Clark, The Righteousness of Noah, „Vetus Testamentum” 21 (1971) nr 3 , s. 261-280, https://doi.org/10.1163/156853371X00407; C. M. Kaminski, Was Noah Good? Finding Favour in the Flood Narrative, New York and London 2014 (The Library of Hebrew Bible; Old Testament Studies, 563), https://doi.org/10.5040/9780567659026; M. D. Jensen, Noah, the Eighth Proclaimer of Righteousness: Understanding 2 Peter 2.5 in Light of Genesis 4.26, ,Journal for the Study of the New Testament” 37 (2015) nr 4, s. 458-469, https://doi. org/10.1177/0142064X15581322; por. J. P. Lewis, A Study of the Interpretation of Noah and the Flood in Jewish and Christian Literature, Leiden 1978. 


\begin{tabular}{|c|c|c|c|c|}
\hline & & Izrael & Patriarchowie & Dynastia Dawidowa \\
\hline 12 & ל & Ochozjasz & Arfachsad & Amazjasz \\
\hline 13 & מם & Achab & Szelach & Joasz \\
\hline 14 & נן & Omri & Heber & Atalia \\
\hline 15 & 0 & Zimri & Peleg & Ochozjasz \\
\hline 16 & ע & Ela & Reu & Joram \\
\hline 17 & פף & Basza & Serug & Jozafat \\
\hline 18 & צין & Nadab & Nachor & Asa \\
\hline 19 & p & Jeroboam I & Terach & Abijjam \\
\hline 20 & 7 & Salomon & Abraham & Roboam \\
\hline 21 & ש & Dawid & Izaak & Salomon \\
\hline 22 & ת & Saul & Jakub & Dawid \\
\hline
\end{tabular}

\section{Manasses i Jeroboam II}

Siódmym patriarchą jest Henoch, który był tak święty, że został wzięty do nieba. Jego zupełnym przeciwieństwem jest siódmy od końca król Izraela Jeroboam II i siódmy od końca król Judy Manasses. Księgi Królewskie przedstawiają Manassesa w bardzo negatywnym świetle, zarzucając mu wprowadzanie w Judzie kultu bogów kananejskich (2 Krl 21, 1-18) ${ }^{12}$. Według autora biblijnego odbudował wyżyny, które zniósł jego ojciec Ezechiasz. W świątyni Pańskiej postawił posąg Aszery,

12 E. Ben Zvi, The Account of the Reign of Manasseh in II Reg 21,1 -18 and the Redactional History of the Book of Kings, ,Zeitschrift für die Alttestamentliche Wissenschaft” 103 (1991) nr 3, s. 355-374, https://doi.org/10.1515/zatw.1991.103.3.355; W. M. Schniedewind, History and Interpretation: The Religion of Ahab and Manasseh in the Book of Kings, „The Catholic Biblical Quarterly” 55 (1993) nr 4, s. 649-661, https://www.jstor.org/stable/43721548; P. S. F. van Keulen, Manasseh Through the Eyes of the Deuteronomists. The Manasseh Account (2 Kings 21:1-18) and the Final Chapters of the Deuteronomistic History, LeidenNew York-Köln 1996 (Oudtestamentische Studiën. Old Testament Studies, 38); K. Schmid, Manasse und der Untergang Judas: "Golaorientierte" Theologie in den Königsbüchern?, „Biblica” 78 (1997) nr 1, s. 87-99, https://doi.org/10.5167/uzh-23300; F. Stavrakopoulou, King Manasseh and Child Sacrifice. Biblical Distortions of Historical Realities, Berlin-New York 2004 (Beihefte zur Zeitschrift für die Alttestamentliche Wissenschaft, 338), https:// doi.org/10.1515/9783110899641. 
a na obydwóch dziedzińcach świątyni budował ołtarze całemu wojsku niebieskiemu, któremu służył. Wznosił także ołtarze Baalowi. Syna swego spalił na ofiarę Molochowi, uprawiał wróżbiarstwo i czary, ustanowił zaklinaczy i wieszczków. Ten bardzo zły obraz Manassesa wydaje się być zamierzonym celem autora Ksiąg Królewskich, gdyż zupełnie inny obraz przedstawia Kronikarz (2 Krn 32, 33-33, 20) ${ }^{13}$. Manasses według Księgi Kronik został porwany do Babilonu, gdzie się nawrócił i dzięki skutecznej modlitwie wybłagał swój powrót do Jerozolimy.

Siódmym królem od końca w genealogii izraelskiej jest Jeroboam II. Autor Ksiąg Królewskich poświęcił mu tylko kilka zdań, chociaż mówi wyraźnie, że Jeroboam II panował ponad 40 lat (2 Krl 14, 23-29). Według 2 Krl 14, 25 władca ten „przywrócił granice Izraela od Wejścia do Chamat aż do morza Araby”. Taka ofensywa polityczno-militarna musiała mieć wiele konsekwencji ${ }^{14}$. Jednak opis jego rządów mieści się zaledwie w kilku wersetach. Uczeni tłumaczą ten stan przeniesieniem wydarzeń z jego czasów na okres panowania Jeroboama ${ }^{15}$. Dotyczy to

13 B. Halpern, Why Manasseh Is Blamed for the Babylonian Exile. The Evolution of a Biblical Tradition, „Vetus Testamentum” 48 (1998) nr 4, s. 473-514, https://doi. org/10.1163/156853398774228417; P. Abadie, From the Impious Manasseh (2 Kings 21) to the Convert Manasseh (2 Chronicles 33). Theological Rewriting by the Chronicler, [w:] The Chronicler as Theologian. Essays in Honor of Ralph W. Klein, ed. M. P. Graham, S. L. McKenzie, G. N. Knoppers, London-New York 2003, s. 89-104 (The Library of Hebrew Bible. Old Testament Studies, 371); A. T. Ohm, Manasseh and the Punishment Narrative, „Tyndale Bulletin” 61 (2010) nr 2, s. 237-254; G. Knoppers, Saint or Sinner? Manasseh in Chronicles, [w:] Rewriting Biblical History. Essays on Chronicles and Ben Sira in Honor of Pancratius C. Beentjes, ed. J. Corley, H. van Grol, Berlin-New York 2011, s. 211-230 (Deuterocanonical and Cognate Literature Studies, 7), https://doi. org/10.1515/9783110240948.211; K. Kinowski, Reinterpretacja historii w Księgach Kronik. Przypadek króla Manassesa, „Collectanea Theologica” 89 (2019) nr 4 s. 139-168 https:// doi.org/10.21697/ct.2019.89.4.05; D. Kucharek, Manasses jako nawrócony król - poszukiwanie przyczyn zmiany punktu widzenia autora 2 Krn 33, 1-20, „Warszawskie Studia Teologiczne” 32 (2019) nr 2, s. 66-83 https://doi.org/10.30439/WST.2019.2.4.

14 M. Vogelstein, Jeroboam II. The Rise and Fall of his Empire, Cincinnati 1945; M. Haran, The Rise and Decline of the Empire of Jeroboam Ben Joash, „Vetus Testamentum” 17 (1967) nr 3, s. 266-297, https://doi.org/10.1163/156853367X00024; por. I. Finkelstein, Stages in the Territorial Expansion of the Northern Kingdom, „Vetus Testamentum” 61 (2011) nr 2, s. 227-242, https://doi.org/10.1163/156853311X571437.

15 T. Römer, How Jeroboam II became Jeroboam I, „Hebrew Bible and Ancient Israel” 6 (2017) nr 3, s. 372-382, https://doi.org/10.1628/219222717X15162808430810; E. A. Knauf, 
szczególnie kultu i sanktuariów w Dan i Betel ${ }^{16}$. Jeroboam I jest obarczony odpowiedzialnością za powstanie państwa północnego oraz jego upadek $^{17}$. Jednak za głęboką schizmę religijną w państwie północnym w rzeczywistości jest odpowiedzialny Jeroboam II. To pod jego rządami następował całkowity upadek moralno-religijny Izraela. Autor biblijny, umieszczając go na siódmym miejscu od końca w genealogii królów

Jeroboam ben Nimshi. The Biblical Evidence, „Hebrew Bible and Ancient Israel” 6 (2017) nr 3, s. 290-307, https://doi.org/10.1628/219222717X15162808430766; por. O. Sergi, The United Monarchy and the Kingdom of Jeroboam II in the Story of Absalom and Sheba's Revolts (2 Samuel 15-20), „Hebrew Bible and Ancient Israel” 6 (2017) nr 3, s. 329-353, https://doi.org/10.1628/219222717X15162808430784; L. L. Grabbe, Jeroboam I? Jeroboam II? Or Jeroboam 0? Jeroboam in History and Tradition, [w:] Rethinking Israel. Studies in the History and Archaeology of Ancient Israel in Honor of Israel Finkelstein, ed. by O. Lipschits, Y. Gadot, M. J. Adams, Winona Lake 2017, s. 115-124.

16 Por. J. Pakkala, Jeroboam without Bulls, „Zeitschrift für die Alttestamentliche Wissenschaft” 120 (2008) nr 4, s. 501-525, https://doi.org/10.1515/ZAW.2008.031; A. R. Davis, Reconstructing the Temple. The Royal Rhetoric of Temple Renovation in the Ancient Near East and Israel, Oxford 2019, s. 155-196, https://doi.org/10.1093/ oso/9780190868963.001.0001; I. Finkelstein, Jeroboam II’s Temples, „Zeitschrift für die Alttestamentliche Wissenschaft” 132 (2020) nr 2, s. 250-265, https://doi.org/10.1515/zaw2020-2004; por. E. Arie, Reconsidering the Iron Age II Strata at Tel Dan. Archaeological and Historical Implications, „Tel Aviv” 35 (2008) nr 1, s. 6-64, https://doi.org/10.1179/ tav.2008.2008.1.6; A. R. Davis, Tel Dan in Its Northern Cultic Context, Atlanta 2013 (Archaeology and Biblical Studies, 20), https://doi.org/10.2307/j.ctt5vjz66; J. S. Greer, Dinner at Dan. Biblical and Archaeological Evidence for Sacred Feasts at Iron Age II Tel Dan and Their Significance, Leiden-Boston 2013 (Culture and History of the Ancient Near East, 66), https://doi.org/10.1163/9789004260627; J. F. Gomes, The Sanctuary of Bethel and the Configuration of Israelite Identity, Berlin-New York 2006 (Beihefte zur Zeitschrift für die alttestamentliche Wissenschaft, 368), https://doi.org/10.1515/9783110925180.

17 R. L. Cohn, Literary Technique in the Jeroboam Narrative, „Zeitschrift für die alttestamentliche Wissenschaft” 97 (1985) nr 1, s. 23-35, https://doi.org/10.1515/zatw.1985.97.1.23; E. Theodore Mullen, Jr., The Sins of Jeroboam. A Redactional Assessments, „The Catholic Biblical Quarterly” 49 (1987) nr 2, s. 212-232, https://www.jstor.org/stable/43717408; P. S. Ash, Jeroboam I and the Deuteronomistic Historian's Ideology of the Founder, „The Catholic Biblical Quarterly” 60 (1998) nr 1, s. 16-24, https://www.jstor.org/stable/43723181; M. Leuchter, Jeroboam the Ephratite, „Journal of Biblical Literature” 125 (2006) nr 1, s. 51-72, https://doi.org/10.2307/27638346; R. A. Geobey, The Jeroboam Story in the (Re) Formulation of Israelite Identity: Evaluating the Literary-Ideological Purposes of 1 Kings 11-14, „The Journal of Hebrew Scriptures” 16 (2016), s. 1-42, https://doi.org/10.5508/ jhs.2016.v16.a2. 
izraelskich, ukazał go jako przeciwieństwo sprawiedliwego i świętego Henocha.

Warto jeszcze zauważyć jeden szczegół, który łączy Manassesa z Jeroboamem II przeciwko Henochowi. Siódmy patriarcha nie dożył sędziwej starości, lecz w „młodym” wieku został zabrany z tego świata. Żył tylko 365 lat, najkrócej z wszystkich patriarchów przed potopem, którzy osiągali wiek prawie tysiąca lat. Natomiast Jeroboam II i Manasses są królami, którzy najdłużej panowali w Izraelu i Judzie. Manasses panował aż 55 lat (2 Krl 21, 1; 2 Krn 33, 1), a Jeroboam II 41 lat $(2 \mathrm{Krl} 14,23)$. Ich zestawienie $\mathrm{z}$ Henochem jako jego przeciwieństwa musiało być redakcyjnym zabiegiem.

\section{Jehu i Jotam}

Dziesiątym patriarchą jest Noe, który uratował istnienie rodzaju ludzkiego i zaczął nową erę w dziejach ludzkości. Dziesiątym od końca królem w linii judzkiej jest Jotam, natomiast dziesiątym władcą od końca w genealogii izraelskiej jest Jehu. Ten ostatni w krwawym przewrocie zakończył panowanie dynastii Omrydów w Izraelu i dał początek zupełnie nowej dynastii (2 Krl 9-10) ${ }^{18}$. Uwagę przykuwa tutaj przychyl-

18 Zob. E. T. Mullen, The Royal Dynastic Grant to Jehu and the Structure of the Books of Kings, „Journal of Biblical Literature” 107 (1988) nr 2, s. 193-206, https://doi. org/10.2307/3267695; M. White, Naboth's Vineyard and Jehu's Coup: the Legitimation of a Dynastic Extermination, „Vetus Testamentum” 44 (1994) nr 1, s. 66-76, https://doi. org/10.1163/156853394X00060; M. S. Moore, Jehu's Coronation and Purge of Israel, „Vetus Testamentum” 53 (2003) nr 1, s. 97-114, https://doi.org/10.1163/156853303321095899; E. Würthwein, Die Revolution Jehus Die Jehu-Erzählung in altisraelitischer und deuteronomistischer Sicht, „Zeitschrift für die alttestamentliche Wissenschaft” 120 (2008) nr 1, s. 28-48, https://doi.org/10.1515/ZAW.2008.003; J. M. Robker, The Jehu Revolution. A Royal Tradition of the Northern Kingdom and Its Ramifications, Berlin-Boston 2012 (Beihefte zur Zeitschrift für die Alttestamentliche Wissenschaft, 435), https://doi. org/10.1515/9783110285017; L. L. D. Mokoena, E. E. Meyer, Jehu's violent coup and the justification of violence, „HTS Teologiese Studies” 75 (2019) nr 3, s. 1-6, https://doi.org/10.4102/ hts.v75i3.5326; por. J. M. Miller, The Fall of the House of Ahab, „Vetus Testamentum” 17 (1967) 3, s. 307-324, https://doi.org/10.1163/156853367X00042; F. O. Garcia-Treto, The Fall of the House. A Carnivalesque Reading of 2 Kings 9 and 10, „Journal for the Study of the Old Testament” 15 (1990) nr 46, s. 47-65, https://doi.org/10.1177/030908929001504605; 
ność autora Ksiąg Królewskich dla zamachu dokonanego przez Jehu, która jest nietypowa. Zabójstwo pomazańca Pańskiego, którym był król Izraela, jest przez tegoż samego autora surowo piętnowane. Widać to na przykładzie chociażby Amalekity przynoszącego Dawidowi wiadomość o dobiciu króla Saula (2 Sm 1, 1-16, zwłaszcza 13-16). Są także spore wątpliwości, czy Jehu rzeczywiście całkowicie usunął Baala z Izraela (por. Oz 2) ${ }^{19}$. Mimo to jest jedynym władcą izraelskim uznanym przez redaktora Ksiąg Królewskich za sprawiedliwego ${ }^{20}$. Autor biblijny umieścił go na dziesiątym od końca miejscu w genealogii izraelskiej, przyrównując go do Noego, gdyż zakończył panowanie dynastii Omrydów, dając początek nowej dynastii, co dla Izraela miało olbrzymie skutki.

Dziesiątym królem od końca w genealogii judzkiej jest Jotam. Z pozoru nie ma on nic wspólnego z Noem. Autor Ksiąg Królewskich niewiele o nim mówi (2 Krl 15, 32-38). Wystarczy jednak przeanalizować tekst biblijny, a okaże się, że dla Judy może być tym, kim jest Noe dla całej ludzkości. Według 2 Krl 15, 37 za jego rządów „Pan zaczął posyłać przeciw Judzie Resina, króla Aramu, i Pekacha, syna Remaliasza”. Oznaczałoby to, że wojna Syro-Efraimska zaczęła się już za rządów Jotama $^{21}$. Nie wszyscy się z tym zgadzają, uważając, że wojna ta była skutkiem przeciwstawienia się mocarstwowym aspiracjom Asyrii ${ }^{22}$. Nie

M. C. White, The Elijah Legends and Jehu's Coup, Atlanta 1997 (Brown Judaica Series, 311); A. Baruchi-Unna, Jehuites, Ahabites, and Omrides: Blood Kinship and Bloodshed, „Journal for the Study of the Old Testament” 42 (2017) nr 1, s. 3-21, https:// doi.org/10.1177/0309089216661177.

19 A. M. King, DidJehu Destroy Baal from Israel? A Contextual Reading ofJehu's Revolt, „Bulletin for Biblical Research” 27 (2017) nr 3, s. 309-332, https://www.jstor.org/stable/10.5325/ bullbiblrese.27.3.0309; por. C. Hubler, 'No Longer Will You Call Me 'My Ba'al'. Hosea's Polemic and the Semantics of 'Ba'al' in 8th Century B.C.E. Israel, „Journal for the Study of the Old Testament” 44 (2020) nr 4, s. 610-623, https://doi.org/10.1177/0309089219862804.

20 Zob. D. T. Lamb, Righteous Jehu and his Evil Heirs. The Deuteronomist's Negative Perspective on Dynastic Succession, Oxford 2007 (Oxford Theological Monographs), https://doi.org/10.1093/acprof:oso/9780199231478.001.0001.

21 B. Oded, The Historical Background of the Syro-Ephraimite War Reconsidered, „The Catholic Biblical Quarterly” 34 (1972) nr 2, s. 151-154, https://www.jstor.org/stable/43713253.

22 J. Begrich, Der Syrisch-Ephraimitische Krieg und seine weltpolitischen Zusammenhänge, „Zeitschrift der Deutschen Morgenländischen Gesellschaft” 83 (1929), s. 213-237, https:// www.jstor.org/stable/43383770. 
ma na to jednak wystarczających dowodów i przyczyn wojny należy poszukać w samym tekście biblijnym ${ }^{23}$.

Według 2 Krl 14, 8-14 doszło do starcia zbrojnego pomiędzy królem judzkim Amazjaszem a królem izraelskim Joaszem, synem Joachaza. Według 2 Krl 14, 13 Joasz, król izraelski, zdobył Jerozolimę, robiąc wyłom w murze miasta od Bramy Efraima aż do Bramy Węgła na czterysta łokci, i zagrabił „całe złoto i srebro, wszystkie przedmioty, które znajdowały się w świątyni Pańskiej i w skarbcach pałacu królewskiego” oraz zabrał ze sobą zakładników do Samarii. Zniszczenie murów obronnych Jerozolimy i przetrzymywanie jej mieszkańców jako zakładników w Samarii oznacza w rzeczywistości okupację Jerozolimy przez króla izraelskiego. Zgadza się to z $2 \mathrm{Krl}$ 14, 25, według której władca izraelski „przywrócił granice Izraela od Wejścia do Chamat aż do morza Araby”, czyli de facto Juda znalazła się pod panowaniem państwa północnego. Co więcej, według 2 Krl 14, 17 „Amazjasz, syn Joasza, króla judzkiego, żył jeszcze piętnaście lat po śmierci Joasza, syna Joachaza, króla izraelskiego”, co stoi w sprzeczności z w. 19, w którym jest mowa spisku przeciwko niemu w Jerozolimie i jego ucieczce do Lakisz, gdzie jednak został zabity. Po nim królem został Azariasz, którego jednak 2 Krl 15, 13. 30. 32. 34; 2 Krn 26, 1nn i Iz 1, 1 nazywają Ozjaszem.

To dziwne zamieszanie z władcami i wyraźna informacja o zdobyciu Jerozolimy przez króla izraelskiego oznaczają, że Juda, a przynajmniej Jerozolima, była w połowie VIII wieku przed Chrystusem pod okupacją północnego państwa ${ }^{24}$. Kilka dekad później doszło do wojny Syro-Efraimskiej ${ }^{25}$. Oznacza to, że w międzyczasie Jerozolima musiała

23 R. Tomes, The Reason for the Syro-Ephraimite War, „Journal for the Study of the Old Testament” 18 (1993) nr 59, s. 61, 64-65, https://doi.org/10.1177/030908929301805904.

24 Por. N. Na'aman, Azariah of Judah and Jeroboam II of Israel, ,Vetus Testamentum” 43 (1993) nr 2, s. 227-234, https://doi.org/10.1163/156853393X00061.

25 Por. M. E. W. Thompson, Situation and Theology. Old Testament Interpretations of the Syro-Ephraimite War, Sheffield 1982 (Prophets and Historians Series, 1); R. Bickert, König Ahas und der Prophet Jesaja. Ein Beitrag zum Problem des syrisch-ephraimitischen Krieges, „Zeitschrift für die Alttestamentliche Wissenschaft” 99 (1987) nr 3, 361-384, https://doi.org/10.1515/zatw.1987.99.3.361; S. A. Irvine, Isaiah, Ahaz, and the Syro-Ephraimitic Crisis, Atlanta 1990 (The Society of Biblical Literature. Monograph Series, 123); C. S. Ehrlich, Coalition Politics in Eighth Century B.C.E. Palestine. The 
zostać uwolniona spod okupacji izraelskiej. Nastąpiło to zapewne za czasów Jotama, kiedy Asyria prowadziła wojnę w północnej Syrii ${ }^{26}$. Wykorzystując sytuację geopolityczną, uwolnił Jerozolimę i Judę spod okupacji izraelskiej. Po zawarciu pokoju z Asyrią połączone siły syryjskie i izraelskie uderzyły na Judę, by podporządkować sobie z powrotem Judę i Jerozolimę. Wojna Syro-Efraimska mogła być więc skutkiem uwolnienia Judy i Jerozolimy spod okupacji izraelskiej.

Król Jotam nie został zatem przypadkowo umieszczony na dziesiątym miejscu od końca w genealogii królów judzkich. Zakończył izraelską okupację Judy i Jerozolimy, dając w ten sposób - tak jak Noe ludzkości - nowy początek Świętemu Miastu. Od tej pory Jerozolima stała się wielkim centrum administracyjnym, politycznym i ludnościowym ${ }^{27}$. Jotam nie był więc drugorzędnym, lecz kluczowym królem dla istnienia Judy i stawianie go na równi z np. Amonem, synem Manassesa, jest niewłaściwe $^{28}$. Nie powinny zatem dziwić rozbieżności pomiędzy biblijnym

Philistines and the Syro-Ephraimite War, „Zeitschrift des Deutschen Palästina-Vereins” 107 (1991), s. 48-58, https://www.jstor.org/stable/27931412; B. Kelle, Hosea 2. Metaphor and Rhetoric in Historical Perspective, Leiden-Boston 2005, s. 192-198 (The Society of Biblical Literature. Academia Biblica, 20).

26 Ten okres przypada na panowanie Tiglat-Pilesera III w Asyrii, który prowadził bardzo intensywne kampanie militarne w różnych regionach Bliskiego Wschodu - por. H. Tadmor, The Inscriptions of Tiglath-pileser III, King of Assyria. Critical Edition with Introductions, Translations and Commentary, Jerusalem 1994; J. K. Kuan, Neo-Assyrian Historical Inscriptions and Syria-Palestine. Israelite/Judean-Tyrian-Damascene Political and Commercial Relations in the Ninth-Eighth Centuries BCE, Eugene 2016, s. 135-192.

27 Por. J. C. von Vaupel Klein, A. Killebrew, Jerusalem in Bible and Archaeology. The First Temple Period, Atlanta 2003 (The Society of Biblical Literature. Symposium, 18); Z. Herzog, L. Singer-Avitz, Redefining the Centre. The Emergence of State in Judah, „Tel Aviv” 31 (2004) nr 2, s. 209-244, https://doi.org/10.1179/tav.2004.2004.2.209; N. Na'aman, When and How Did Jerusalem Become a Great City? The Rise of Jerusalem as Judah's Premier City in the Eighth-Seventh Centuries B.C.E., „Bulletin of the American Schools of Oriental Research” 347 (2007), s. 21-56, https://doi.org/10.1086/BASOR25067021; I. Finkelstein, The Settlement History of Jerusalem in the Eighth and Seventh Centuries BC, „Revue Biblique” 115 (2008) nr 4, s. 499-515, https://doi.org/10.2143/RBI.115.4.3206463; N. Na'aman, The Growth and Development of Judah and Jerusalem in the Eighth Century BCE. A Rejoinder, „Revue Biblique” 116 (2009) nr 3, s. 321-335, https://doi.org/10.2143/RBI.116.3.3206430.

28 Por. C. Begg, Jotham and Amon. Two Minor Kings of Judah According to Josephus, „Bulletin for Biblical Research” 6 (1996), s. 1-13, https://www.jstor.org/stable/26422137. 
opisem odsieczy asyryjskiej a źródłami asyryjskimi ${ }^{29}$. Natomiast inną sprawą jest - tak jak w przypadku Jeroboama II - przemilczenie przez autora Ksiąg Królewskich jego rzeczywistych zasług, a jedynie umieszczenie go w nieprzypadkowym miejscu genealogii królów judzkich.

\section{Jozjasz i Szallum}

W Biblii Hebrajskiej szczególne znaczenie ma także liczba pięć. Torah składa się z pięciu ksiąg, Księga Psalmów jest także podzielona na pięć części, a Pieśń nad pieśniami, Księga Rut, Lamentacje Jeremiasza, Księga Koheleta i Księga Estery to w Biblii hebrajskiej tzw. księgi pięciu megilot. Nie ma tutaj miejsca, by omawiać wszystkie przykłady, choć można ich podać więcej ${ }^{30}$. Skoro autor Ksiąg Królewskich umieścił siódmego i dziesiątego od końca króla w genealogii zarówno izraelskiej, jak i judzkiej według swojej koncepcji, a nie rzeczywistej sukcesji, to można oczekiwać, że podobnie mógł zrobić z piątymi od końca królami w obu liniach. Te przypuszczenia zdają się być uzasadnione. Piątym od końca w genealogii królów izraelskich jest Szallum, a piątym od końca w linii judzkiej - Jozjasz. Obaj mają wspólną cechę: nie umarli w podeszłym wieku śmiercią naturalną, lecz zginęli zabici przez wroga. Co więcej, śmierć Jozjasza była dużym zaskoczeniem i rozczarowaniem dla Judy ${ }^{31}$.

29 Zob. L. R. Siddall, Tiglath-pileser III's Aid to Ahaz. A New Look at the Problems of the Biblical Accounts in Light of the Assyrian Sources, „Ancient Near Eastern Studies” 46 (2009), s. 93-106, https://doi.org/10.2143/ANES.46.0.2040712; P. Dubovský, Tiglath-pileser III's Campaigns in 734-732 B.C. Historical Background of Isa 7; $2 \mathrm{Kgs} \mathrm{15-16} \mathrm{and} 2 \mathrm{Chr} 27-28$, „Biblica” 87 (2006) nr 2, s. 153-170, https://doi.org/10.2143/BIB.87.2.3189037; G. Galil, A New Look at the Inscriptions of Tiglath-pileser III, „Biblica” 81 (2000) nr 4, s. 511-520, https://doi.org/10.2143/BIB.81.4.3200456; N. Na'aman, Tiglath-pileser III's Campaigns Against Tyre and Israel (734-732 B.C.E.), „Tel Aviv” 22 (1995) nr 2, s. 268-278, https://doi. org/10.1179/tav.1995.1995.2.268.

30 Co ciekawe, Bóg zmienia imię Abramowi składające się z czterech liter אברם na Abraham, które składa się z pięciu liter אברהם (Rdz 17, 5), a Jakub, którego imię zawiera cztery litery יעקב, otrzymuje nowe imię, Izrael, które składa się z pięciu liter ישראל (Rdz 32, 29).

31 Cf. A. Laato, Josiah and David Redivivus. The Historical Josiah and the Messianic Expectations of Exilic and Postexilic Times, Stockholm 1992 (Coniectanea Biblica, Old Testament Series, 33). 
Jednak trudno o niej powiedzieć coś więcej32. Może jest więc wynikiem pracy redaktora Ksiąg Królewskich ${ }^{33}$. Umieszczenie zatem Jozjasza i Szalluma na piątym miejscu od końca w genealogii królów judzkich i izraelskich może być wynikiem pracy redakcyjnej autora biblijnego i nie odzwierciedlać ich rzeczywistej sukcesji.

\section{Jeroboam I i Abijjam}

Warto jeszcze zwrócić uwagę na jedno zestawienie królów z patriarchą, a mianowicie czwartego króla izraelskiego Jeroboama I i judzkiego Abijjama z czwartym od końca patriarchą Terachem. Ojciec Abrahama był politeistą. Jeroboam I porzucił religię Izraela i stał się schizmatykiem (1 Krl 12, 25-33) ${ }^{34}$. Jego odpowiednikiem według tego klucza jest Abijjam. Księgi Królewskie mówią, że „poszedł on drogą wszelkich

32 S. B. Frost, The Death of Josiah. A Conspiracy of Silence, „Journal of Biblical Literature” 87 (1968) nr 4, s. 369-382, https://doi.org/10.2307/3263298; C. Begg, The Death of Josiah. Josephus and the Bible, „Ephemerides Theologicae Lovanienses” 64 (1988) nr 1, s. 157-163, https://doi.org/10.2143/ETL.64.1.556378; M. A. Sweeney, King Josiah of Judah. The Lost Messiah of Israel, Oxford 2001, https://doi.org/10.1093/0195133242.001.0001.

33 Cf. H. G. M. Williamson, The Death of Josiah and the Continuing Development of the Deuteronomic History, „Vetus Testamentum” 32 (1982) nr 2, s. 242-248, https://doi. org/10.1163/156853382X00135; C. T. Begg, The Death of Josiah in Chronicles: Another View, „Vetus Testamentum” 37 (1987) nr 1-4, s. 1-8, https://doi.org/10.1163/156853387X00013; H. G. M. Williamson, Reliving the Death ofJosiah: a Reply To C. T. Begg, „Vetus Testamentum” 37 (1987) nr 1-4, s. 9-15, https://doi.org/10.1163/156853387X00022; Z. Talshir, The Three Deaths of Josiah and the Strata of Biblical Historiography (2 Kings XXIII 29-30; 2 Chronicles XXXV 20-5; 1 Esdras I 23-31), „Vetus Testamentum” 46 (1996) nr 2, s. 213-236, https:// doi.org/10.1163/1568533962580793; S. Delamarter, The Death of Josiah in Scripture and Tradition: Wrestling with the Problem of Evil?, „Vetus Testamentum” 54 (2004) nr 1, s. 29-60, https://doi.org/10.1163/156853304772932924; C. Mitchell, The Ironic Death of Josiah in 2 Chronicles, „The Catholic Biblical Quarterly” 68 (2006) nr 3, s. 421-435, http:// doi.org/10.17613/M6SC6B.

34 J. Debus, Die Sünde Jerobeams, Göttingen 1968 (Forschungen zur Religion und Literatur des Alten und Neuen Testaments 93), https://doi.org/10.13109/9783666531996; W. I. Toews, Monarchy and Religious Institutions in Israel under Jeroboam I, Atlanta 1993 (The Society of Biblical Literature. Monograph Series, 47); T. Tułodziecki, Jeroboam IReformator religii Izraela. Studium egzegetyczno-teologiczne 1 Krl 11, 26-14, 20, Warszawa 2004 (Rozprawy i Studia Biblijne, 14). 
grzechów swego ojca, które przed nim popełniał, dlatego że serce jego nie było szczere wobec Pana, Boga swego” (1 Krl 15, 3a). Zupełnie inny obraz przedstawiają Księgi Kronik (2 Krn 13, 1-23), które dały mu nawet inne imię Abiasz (hebr. Abijahu - „ojcem moim jest Jahwe”) ${ }^{35}$. Ta różnica sugeruje, że autor Ksiąg Królewskich celowo przedstawił Abijjama w negatywnym świetle, ukazując go jako judzki odpowiednik Jeroboama I. Należy tutaj zauważyć, że Abijjam i Jeroboam I są dziewiętnastymi królami od końca. W Księdze Psalmów 19 i 119 są psalmami mądrościowymi ${ }^{36}$. Autor Ksiąg Królewskich mógł zatem uważać Abijjama i Jeroboama I za zaprzeczenie (odwrócenie) mądrości.

\section{Podsumowanie}

Tych kilka spostrzeżeń prowadzi do ważnych konkluzji. Genealogie królów izraelskich i judzkich są wynikiem głębokiej pracy redakcyjnej autora biblijnego i nie odzwierciedlają rzeczywistej sukcesji. Liczba władców w obu królestwach nie jest przypadkowa, lecz odpowiada liczbie patriarchów i liter w alfabecie hebrajskim. Autor w ten sposób chciał powiedzieć, że epoka królewska w starożytnym Izraelu jest - tak jak epoka patriarchów - pełnym i zamkniętym już okresem w historii

35 R. W. Klein, Abijah's Campaign Against the North (II Chr 13) - What Were the Chronicler's Sources?, „Zeitschrift für die alttestamentliche Wissenschaft” 95 (1983) nr 2, s. 210-217, https://doi.org/10.1515/zatw.1983.95.2.210; D. G. Deboys, History and Theology in the Chronicler's Portrayal of Abijah, „Biblica” 71 (1990) nr 1, s. 48-62, https://doi.org/10.2143/ BIB.71.1.3217747; G. H. Jones, From Abijam to Abijah, „Zeitschrift für die Alttestamentliche Wissenschaft” 106 (1994) nr 3, s. 420-434, https://doi.org/10.1515/zatw.1994.106.3.420.

36 J. L. Mays, The Place of the Torah-Psalms in the Psalter, „Journal of Biblical Literature” 106 (1987) nr 1, s. 3-12 https://doi.org/10.2307/3260550; J.-Y. Bang, The Canonical Function of Psalms 19 and 119 as a Macro-Torah-Frame, „The Korean Journal of Old Testament Studies” 23 (2017) nr 4, s. 251-285, http://doi.org/10.24333/jkots.2017.23.4.251; por. A. Lenzi, The Metonic Cycle, Number Symbolism, and the Placement of Psalms 19 and 119 in the MT Psalter, ,Journal for the Study of the Old Testament” 34 (2010) nr 4, s. 447-473, https://doi.org/10.1177/0309089210372847; B. D. Sommer, Nature, Revelation, and Grace in Psalm 19: Towards a Theological Reading of Scripture, „Harvard Theological Review” 108 (2015) nr 3, s. 376-401, https://doi.org/10.1017/S0017816015000243. 
Narodu Wybranego ${ }^{37}$. Genealogie królów Izraela i Judy są tak skomponowane, że są odwróceniem (przeciwstawieniem) genealogii patriarchów. Autor Ksiąg Królewskich wyraził w ten sposób swoją negatywną ocenę epoki królewskiej. Szczególnie widać to na przykładzie Jehu i Jotama oraz Manassesa i Jeroboama II, którzy mieli być antytypami odpowiednio Noego i Henocha.

Jeśli redaktor Ksiąg Królewskich tak ułożył genealogie królów Izraela i Judy, że dziesiątym od końca królem izraelskim miał być Jehu, a dziesiątym od końca królem judzkim miał być Jotam, to obie linie władców zostały tak dopasowane, by zarówno po Jehu, jak i po Jotamie było dokładnie dziewięciu królów aż do upadku każdego z obu królestw. Oznacza to jednocześnie, że przed Jehu i przed Jotamem musiało być dokładnie 12 królów w obu królestwach. Jeśli siódmym od końca królem judzkim miał być Manasses, a siódmym od końca królem izraelskim miał być Jeroboam II jako przeciwieństwa świętego Henocha, to po Jeroboamie II i Manassesie musiało być dokładnie sześciu władców w obu genealogiach. Po Jehu i Jotamie oraz po Jeroboamie II i Manassesie niektórzy królowie mogli więc zostać dodani bądź opuszczeni ze względów redakcyjnych, tak by Jehu i Jotam byli dziesiątymi królami od końca, a Jeroboam II i Manasses byli siódmymi królami od końca. Natomiast pomiędzy Jehu i Jeroboamem II oraz pomiędzy Jotamem i Manassesem musiało być dokładnie po dwóch królów. Co więcej, przed Jehu i przed Jotamem niektórzy królowie mogli zostać dodani bądź opuszczeni, by

37 Por. E. Zenger, Die deuteronomistische Interpretation der Rehabilitierung Jojachins, „Biblische Zeitschrift” 12 (1968), s. 16-31; J. D. Levenson, The Last Four Verses in Kings, „Journal of Biblical Literature” 103 (1984) nr 3, s. 353-361, https://doi. org/10.2307/3260777; C. T. Begg, The Significance of Jehoiachin's Release: a New Proposal, „Journal for the Study of the Old Testament” 11 (1986) nr 36, s. 49-56, https://doi. org/10.1177/030908928601103604; J. G. Mcconville, Narrative and Meaning in the Books of Kings, „Biblica” 70 (1989) nr 1, s. 31-49, https://doi.org/10.2143/BIB.70.1.3217784; D. F. Murray, Of All the Years the Hopes: Or Fears? Jehoiachin in Babylon (2 Kings 25:27-30), „Journal of Biblical Literature” 120 (2001) nr 2, s. 245-265, https://doi.org/10.2307/3268294; D. Janzen, An Ambiguous Ending. Dynastic Punishment in Kings and the Fate of the Davidides in 2 Kings 25.27-30, ,Journal for the Study of the Old Testament” 33 (2008) nr 1, s. 39-58, https://doi.org/10.1177/0309089208094459; D. Janzen, The Sins of Josiah and Hezekiah. A Synchronic Reading of the Final Chapters of Kings, „Journal for the Study of the Old Testament” 37 (2013) nr 3, s. 349-370, https://doi.org/10.1177/0309089213475396. 
przed tymi dwoma królami było dokładnie 12 władców. Jeśli Jozjasz i Szallum mieli być piątymi królami od końca w obu genealogiach, to po nich zostało umieszczonych dokładnie czterech władców w obu liniach niezależnie od rzeczywistej sukcesji ${ }^{38}$.

\begin{tabular}{|c|c|c|c|c|}
\hline & Izrael & & Dynastia Dawidowa & \\
\hline 1 & Saul & \multirow{12}{*}{$\begin{array}{l}\text { Dokładnie } 12 \text { królów w obu genealogiach, } \\
\text { by Jehu i Jotam byli dziesiątymi królami od końca }\end{array}$} & Dawid & 22 \\
\hline 2 & Dawid & & Salomon & 21 \\
\hline 3 & Salomon & & Roboam & 20 \\
\hline 4 & Jeroboam I & & Abijjam & 19 \\
\hline 5 & Nadab & & Asa & 18 \\
\hline 6 & Basza & & Jozafat & 17 \\
\hline 7 & Ela & & Joram & 16 \\
\hline 8 & Zimri & & Ochozjasz & 15 \\
\hline 9 & Omri & & Atalia & 14 \\
\hline 10 & Achab & & Joasz & 13 \\
\hline 11 & Ochozjasz & & Amazjasz & 12 \\
\hline 12 & Joram & & Azariasz & 11 \\
\hline 13 & JEHU & Antytypy Noego & JOTAM & 10 \\
\hline 14 & Joachaz & \multirow{2}{*}{$\begin{array}{l}\text { Dokładnie dwóch królów pomiędzy dziesiątym i siódmym } \\
\text { władcą w obu genealogiach }\end{array}$} & Achaz & 9 \\
\hline 15 & Joasz & & Ezechiasz & 8 \\
\hline 16 & JEROBOAM II & Antytypy Henocha & MANASSES & 7 \\
\hline 17 & Zachariasz & \multirow{6}{*}{$\begin{array}{l}\text { Sześciu królów w obu genealogiach ze względu } \\
\text { na siódme miejsce od końca } \\
\text { Jeroboama II i Manassesa } \\
\text { jako antytypów Henocha, siódmego patriarchy }\end{array}$} & Amon & 6 \\
\hline 18 & Szallum & & Jozjasz & 5 \\
\hline 19 & Menachem & & Joachaz & 4 \\
\hline 20 & Pekachiasz & & Jojakim & 3 \\
\hline 21 & Pekach & & Jojakin & 2 \\
\hline 22 & Ozeasz & & Sedecjasz & 1 \\
\hline
\end{tabular}

38 Zob. np. A. R. Green, The Chronology of the Last Days of Judah. Two Apparent Discrepancies, „Journal of Biblical Literature” 101 (1982) 1, s. 57-73, https://doi. org/10.2307/3260440; J. H. Hayes, J. K. Kuan, The Final Years of Samaria (730-720 BC), „Biblica” 72 (1991) nr 2, s. 153-181, https://doi.org/10.2143/BIB.72.2.3217713; Ł. K. Toboła, Imiona królów judzkich - kilka spostrzeżeń, „The Biblical Annals” 6 (2016) nr 4, s. 601-610, https://czasopisma.kul.pl/ba/article/view/1202. 
Nie powinny zatem dziwić trudności w ustaleniu chronologii dziejów Izraela, szczególnie pod koniec IX wieku oraz w VIII wieku przed Chrystusem $^{39}$. W tym świetle zrozumiałe są także problemy z ustaleniem dokładnych dat panowania władców judzkich dla okresu od połowy VIII wieku do początku VI wieku przed Chrystusem ${ }^{40}$. Dotyczy to szczególnie ostatnich lat w obu królestwach, które sprawiają najwięcej trudności.

Jeśli Jehu, Jotam, Manasses i Jeroboam II zostali wstawieni do genealogii królów izraelskich i judzkich wbrew rzeczywistej sukcesji, to taki zabieg redakcyjny mógł spowodować powikłania pomiędzy ich panowaniem a rządami ich poprzedników lub ich następców. W tym świetle zrozumiałe stają się trudności z pokrywaniem się panowania Jotama, Manassesa oraz Jeroboama II z ich poprzednikami, które tłumaczy się koregencją, tzn. współrządami z ich poprzednikami. Nie byłyby one zatem rzeczywistymi wspólnymi okresami panowania tych trzech władców oraz ich poprzedników, lecz skutkiem ubocznym koncepcji autora biblijnego, który Jotama, Manassesa oraz Jeroboama II wstawił do genealogii królów judzkich i izraelskich na dziesiątym i siódmym

39 H. Hänsler, Die biblische Chronologie des 8. Jahrhunderts v. Chr. Ein Lösungsversuch der Schwierigkeiten in der Zeitrechnung der hl. Schrift, „Biblica” 10 (1929) nr 3, s. 257-274, https://www.jstor.org/stable/42617354; H. Hänsler, Die biblische Chronologie des 8. Jahrhunderts v. Chr. Ein Lösungsversuch der Schwierigkeiten in der Zeitrechnung der hl. Schrift (Cont.), „Biblica” 10 (1929) nr 4, s. 377-393, https://www.jstor.org/stable/42613792; K. Weingart, 2 Kings 15-18. a Chronological Conundrum?, [w:] The Last Days of the Kingdom of Israel, ed. S. Hasegawa, C. Levin and K. Radner, Berlin-Boston 2019, s. 267-288, (Beihefte zur Zeitschrift für die Alttestamentliche Wissenschaft, 511), https://doi.org/10.1515/9783110566604-013; S. L. McKenzie, The Last Days of Israel. Chronological Considerations, [w:] The Last Days of the Kingdom of Israel, ed. S. Hasegawa, C. Levin and K. Radner, Berlin-Boston 2019, s. 289-300 (Beihefte zur Zeitschrift für die Alttestamentliche Wissenschaft, 511), https://doi.org/10.1515/9783110566604-014.

40 A. Laato, New Viewpoints on the Chronology of the Kings of Judah and Israel, ,Zeitschrift für die Alttestamentliche Wissenschaft” 98 (1986) nr 2, s. 210-221, https://doi.org/10.1515/ zatw.1986.98.2.210; G. Galil, The Babylonian Calendar and the Chronology of the Last Kings of Judah, „Biblica” 72 (1991) nr 3, s. 367-378, https://www.jstor.org/stable/42611193; S. Dalley, Recent Evidence from Assyrian Sources for Judaean History from Uzziah to Manasseh, ,Journal for the Study of the Old Testament” 28 (2004) nr 4, s. 387-401, https:// doi.org/10.1177/030908920402800401. 
miejscu od końca wbrew rzeczywistej sukcesji. W rzeczywistości koregencji mogło wcale nie być ${ }^{41}$.

Nie powinny zatem także dziwić niejasności co do pokrewieństwa pomiędzy Joramem i Ochozjaszem, które mogą wynikać z umiejscowienia Jehu jako dziesiątego od końca króla w genealogii izraelskiej, ponieważ przed Jehu musiało być dokładnie 12 królów w państwie północnym. To samo odnosi się do trudności z Achazem i Ezechiaszem, czyli dziewiątym i ósmym królem od końca w genealogii judzkiej, ponieważ pomiędzy Jotamem i Manassesem, czyli dziesiątym i siódmym królem od końca w Judzie, musiało być - zgodnie z zamysłem redaktora Ksiąg Królewskich - tylko dwóch królów oraz tylko dwóch królów izraelskich pomiędzy Jehu i Jeroboamem $\mathrm{II}^{42}$. Skoro przed Jehu i Jotamem musiało być w obu genealogiach dokładnie 12 władców, to łatwo zrozumieć wyniki niektórych badań, które sugerują, że Joram izraelski oraz Joram judejski byli jedną i tą samą osobą ${ }^{43}$. Joram mógł zostać zaliczony do obu królestw ze względu na koncepcję autora biblijnego, która - niezależnie od rzeczywistej sukcesji - wymagała dokładnie 12 władców w obu genealogiach.

W tym świetle łatwo także zrozumieć problem z liczbą lat panowania Jotama, która według 2 Krl 15, 33 wynosi 16 lat. Nastręcza ona

41 Por. jednak E. Thiele, Coregencies and Overlapping Reigns among the Hebrew Kings, ,Journal of Biblical Literature” 93 (1974) nr 2, s. 174-200, https://doi.org/10.2307/3263092; E. Ball, The Co-Regency of David and Solomon (1 Kings I), „Vetus Testamentum” 27 (1977) nr 3, s. 268-279, https://doi.org/10.1163/156853377X00168.

42 Por. J. Strange, Joram, King of Israel and Judah, „Vetus Testamentum” 25 (1975) nr 2, s. 191201, https://doi.org/10.2307/1517266; D. V. Etz, The Genealogical Relationships of Jehoram and Ahaziah, and of Ahaz and Hezekiah, Kings of Judah, ,Journal for the Study of the Old Testament” 21 (1996) 71, s. 39-53, https://doi.org/10.1177/030908929602107104; W. Barrick, Another Shaking Of Jehoshaphat's Family Tree. Jehoram And Ahaziah Once Again, „Vetus Testamentum” 51 (2001) nr 1, s. 9-25, https://doi.org/10.1163/156853301300102174.

43 P. K. McCarter, "Yaw, Son of 'Omri”: A Philological Note on Israelite Chronology, „Bulletin of the American Schools of Oriental Research” 216 (1974), s. 5-7, https://doi. org/10.2307/1356327; J. Strange, Joram, King of Israel and Judah, „Vetus Testamentum” 25 (1975) nr 2, s. 191-201, https://doi.org/10.2307/1517266; E. R. Thiele, An Additional Chronological Note on "Yaw, Son of 'Omri”, „Bulletin of the American Schools of Oriental Research” 222 (1976), s. 19-23, https://doi.org/10.2307/1356296; M. Weippert, Jau(a) Mar Aumrî - Joram Oder Jehu Von Israel?, „Vetus Testamentum” 28 (1978) nr 1, s. 113-118, https://doi.org/10.1163/156853378X00356. 
poważnych trudności dla chronologii królów judzkich i liczbę tę uczeni albo redukują, albo przyjmują lata jego koregencji. Według $2 \operatorname{Krl~15,~} 5$ Azariasz zachorował na trąd. Chorobą tą autor Ksiąg Królewskich wyjaśnia dziwną sytuację polityczną, w której faktyczną władzę sprawował Jotam. Zupełnie inaczej na jego chorobę patrzą autor Ksiąg Kronik oraz Józef Flawiusz ${ }^{44}$. Jeśli według koncepcji autora biblijnego Jotam miał być dziesiątym królem judzkim od końca, ale jego rządy zazębiały się z rządami Ozjasza, to autor Ksiąg Królewskich mógł próbować wyjaśnić tę dziwną sytuację polityczną trądem dotychczasowego władcy.

Autor biblijny nie tylko przeciwstawił epokę królewską epoce patriarchów, ale tak ułożył obie genealogie władców - izraelskich i judzkich, że są paralelne: Jehu jest odpowiednikiem Jotama, Jeroboam II - Manassesa, Jozjasz - Szalluma, a Abijjam - Jeroboama I. Izrael i Juda są traktowani jako równorzędni przedstawiciele Narodu Wybranego ${ }^{45}$. Przemawia to za powstaniem Ksiąg Samuela i Królewskich w niewoli babilońskiej ${ }^{46}$. Po powrocie z niewoli babilońskiej sytuacja zmieniła się diametralnie ${ }^{47}$. Księgi Samuela i Królewskie posiadają specyficz-

44 I. Cranz, The motif of Uzziah's צרעת in the Deuteronomistic History, Chronicles, and beyond, „Journal for the Study of the Old Testament” 44 (2019) nr 2, s. 233-249, https://doi. org $/ 10.1177 / 0309089218755558$.

45 Por. H. N. Wallace, The Oracles against the Israelite Dynasties in 1 and 2 Kings, „Biblica” 67 (1986) nr 1, s. 21-40, https://doi.org/10.2143/BIB.67.1.3217951; C. Levin, Das synchronistische Exzerpt aus den Annalen der Könige von Israel und Juda, „Vetus Testamentum” 61 (2011) nr 4, s. 616-628, https://doi.org/10.1163/156853311X560772.

46 Por. G. N. Knoppers, Theories of the Redaction(s) of Kings, [w:] The Books of Kings. Sources, Composition, Historiography and Reception, ed. B. Halpern, A. Lemaire, LeidenBoston 2010, s. 67-88 (Vetus Testamentum, Supplements, 129), https://doi.org/10.1163/ ej.9789004177291.i-712.23; H. Weippert, Die “deuteronomistischen” Beurteilungen der Könige von Israel und Juda und das Problem der Redaktion der Königsbücher, „Biblica” 53 (1972) nr 3, s. 301-339, https://www.jstor.org/stable/42610051.

47 W. Chrostowski, Konflikt wokół odbudowy świątyni (Ezd 4, 1-5). Przyczynek do transformacji religii biblijnego Izraela i narodzin judaizmu, „Collectanea Theologica” 89 (2019) nr 3, s. 43-84, https://doi.org/10.21697/ct.2019.89.3.02; por. W. Chrostowski, Kronikarskie dzieło historyczne jako projekt nowej przyszłości Izraela, „Collectanea Theologica” 89 (2019) nr 4, s. 7-46, https://doi.org/10.21697/ct.2019.89.4.01; B. Hensel, On the Relationship of Judah and Samaria in Post-Exilic Times. A Farewell to the Conflict Paradigm, „Journal for the Study of the Old Testament” 44 (2019) nr 1, s. 19-42, https://doi.org/10.1177/0309089217748304. 
ną teologię ${ }^{48}$. Natomiast Księgi Kronik, napisane później niż Samuela i Królewskie, cechują się innym spojrzeniem na historię Izraela ${ }^{49}$. Autor Ksiąg Kronik korzysta z Ksiąg Samuela i Królewskich, ale je gruntownie przeredagowuje ${ }^{50}$. Przede wszystkim nie uznaje legalności władzy państwa północnego, uważając ją jako uzurpację i schizmę wobec Judy i Jerozolimy ${ }^{51}$. Co więcej, według Oz 5, 5 istniały nie dwa, lecz trzy państwa izraelskie: Juda, Izrael i Efraim ${ }^{52}$. Nie istniały zatem tylko dwa narody Boże ${ }^{53}$. Autor Ksiąg Królewskich przedstawił jednak tylko dwie genealogie, i to równe sobie. To równe traktowanie Izraela i Judy

48 K. Bodner, The Theology of the Book of Kings, Cambridge 2019 (Old Testament Theology), https://doi.org/10.1017/9781316414910.

49 E. Zawiszewski, Księgi Kronik - apologia czy historia, „Ruch Biblijny i Liturgiczny” 21 (1968) $\mathrm{nr}$ 4-5, s. 233-237, https://doi.org/10.21906/rbl.3142; H. Witczyk, Historycznoprorockie tło Dzieła Kronikarskiego, „Ruch Biblijny i Liturgiczny” 49 (1996) nr 1, s. 1-14, https://doi.org/10.21906/rbl.793; L. Jonker, Reforming History. The Hermeneutical Significance of the Books of Chronicles, „Vetus Testamentum” 57 (2007) nr 1, s. 21-44, https://doi.org/10.1163/156853307X167846; por. D. Dziadosz, Między historia, ideologia i teologia. Pro-Dawidowa lektura tradycji o Saulu w Pierwszej Księdze Kronik, „Collectanea Theologica” 89 (2019) nr 4, s. 47-93, https://doi.org/10.21697/ct.2019.89.4.02.

50 Zob. I. Kalimi, The Reshaping of Ancient Israelite History in Chronicles, Winona Lake 2005; P. C. Beentjes, Tradition and Transformation in the Book of Chronicles, Leiden-Boston 2008 (Studia Semitica Neerlandica, 52) https://doi.org/10.1163/ej.9789004170445.i-214; I. Kalimi, Kings with Privilege. The Core Source(s) of the Parallel Texts between the Deuteronomistic and Chronistic, „Revue Biblique” 119 (2012) nr 4, s. 498-517, https://doi. org/10.2143/RBI.119.4.3203549; por. W. E. Lemke, The Synoptic Problem in the Chronicler's History, „Harvard Theological Review” 58 (1965) nr 4, s. 349-363, https://doi.org/10.1017/ S0017816000002583; S. L. McKenzie, The Chronicler's Use of the Deuteronomistic History, Atlanta 1984 (Harvard Semitic Monographs, 33).

51 H. G. M. Williamson, Israel in the Books of Chronicles, Cambridge 1977, https://doi. org/10.1017/СBO9780511557453.

52 E. R. Thiele, The Mysterious Numbers of the Hebrew Kings. New Revised Edition, Grand Rapids 1994, s. 61, przypis 1.

53 Por. np. G. N. Knoppers, Two Nations Under God: The Deuteronomistic History of Solomon and the Dual Monarchies, t. 1: The Reign of Solomon and the Rise of Jeroboam, Leiden 1993 (Harvard Semitic Monographs, 52), https://doi.org/10.1163/9789004369689; G. N. Knoppers, Two Nations Under God: The Deuteronomistic History of Solomon and the Dual Monarchies, t. 2: The Reign of Jeroboam, the Fall of Israel, and the Reign of Josiah, Leiden 1994 (Harvard Semitic Monographs, 53), https://doi.org/10.1163/9789004369696; S. Gelander, From Two Kingdoms To One Nation - Israel and Judah. Studies in Division and Unification, Leiden 2011 (Studia Semitica Neerlandica, 56), https://doi.org/10.1163/ ej.9789004203464.i-260. 
oraz pominięcie Efraima może świadczyć, że w niewoli babilońskiej doszło do spotkania babilońskiej diaspory judzkiej z asyryjską diasporą izraelskąa ${ }^{54}$. Niewola babilońska tłumaczyłaby także wzorowanie się autora Ksiąg Samuela i Królewskich przy komponowaniu list królów izraelskich i judzkich na arytmetycznym układaniu genealogii znanym w Babilonii ${ }^{55}$. Skoro genealogie królów izraelskich i judzkich są powiązane z genealogią patriarchów, to jest możliwe, że i genealogie patriarchów mogły być wzorowane na pozabiblijnych źródłach ${ }^{56}$.

Powyższe spostrzeżenia dotyczące dziesiątego, siódmego, piątego oraz dziewiętnastego króla od końca w obu genealogiach rzucają nowe światło także na datę zniszczenia świątyni jerozolimskiej zbudowanej przez Salomona ${ }^{57}$. Według 2 Krl 25, 8-9 zniszczono ją siódmego dnia piątego miesiąca dziewiętnastego roku panowania króla babilońskiego Nabuchodonozora. Jednak Jeremiasz podaje inną datę spalenia świątyni Pańskiej niż Księgi Królewskie ${ }^{58}$. Data z 2 Krl 25, 8-9 nawiązuje do spostrzeżeń dotyczących genealogii królów izraelskich i judzkich: siódmy

54 W. Chrostowski, Asyryjska diaspora Izraelitów jako wyzwanie dla biblistyki i asyriologii, „Collectanea Theologica” 86 (2016) nr 3, s. 5-26, https://doi.org/10.21697/ct.2016.86.3.01; W. Chrostowski, Asyryjska diaspora Izraelitów w świetle Księgi Ezechiela - Wojciechowi Pikorowi w odpowiedzi, „The Biblical Annals” 2 (2015) nr 1, s. 75-122; W. Chrostowski, Asyryjska diaspora Izraelitów i inne studia, Warszawa 2003 (Rozprawy i Studia Biblijne, 10); W. Chrostowski, Ogród Eden. Zapoznane świadectwo asyryjskiej diaspory, Warszawa 1996 (Rozprawy i Studia Biblijne, 1).

55 Zob. J. Høyrup, “Remarkable Numbers” in Old Babylonian Mathematical Texts. A Note on the Psychology of Numbers, „Journal of Near Eastern Studies” 52 (1993) nr 4, s. 281-286, https://doi.org/10.1086/373636; D. Young, A Mathematical Approach to Certain Dynastic Spans in the Sumerian King List, ,Journal of Near Eastern Studies” 47 (1988) nr 2, s. 123 129, https://doi.org/10.1086/373263.

56 T. C. Hartman, Some Thoughts on the Sumerian King List and Genesis 5 and 11B, ,Journal of Biblical Literature” 91 (1972) nr 1, s. 25-32, https://doi.org/10.2307/3262917; A. Malamat, King Lists of the Old Babylonian Period and Biblical Genealogies, ,Journal of the American Oriental Society” 88 (1968) nr 1, s. 163-173, https://doi.org/10.2307/597910; J. Walton, The Antediluvian Section of the Sumerian King List and Genesis 5, „The Biblical Archaeologist” 44 (1981) nr 4, s. 207-208, https://doi.org/10.2307/3209665.

57 Por. M. Avioz, When Was the First Temple Destroyed, According to the Bible?, „Biblica” 84 (2003) nr 4, s. 562-565, https://doi.org/10.2143/BIB.84.4.3194492.

$58 \mathrm{Na}$ temat Jr 52 i jego relacji do $2 \mathrm{Krl} 25$ zob. H. de Waard, Jeremiah 52 in the Context of the Book of Jeremiah, Leiden 2020 (Vetus Testamentum Supplements, 183), https://doi. org/10.1163/9789004423558. 
dzień - siódmy od końca Jeroboam II i Manasses; piąty miesiąc - piąty od końca Jozjasz i Szallum; dziewiętnasty rok - dziewiętnasty od końca Jeroboam I i Abijjam. Jeśli rzeczywistą datę końca Pierwszej Świątyni zawiera Jr 52 (piąty miesiąc dziesiąty dzień dziewiętnasty rok rządów Nabuchodonozora), to autor Ksiąg Królewskich mógł łatwo ją przystosować do własnej koncepcji (piąty miesiąc siódmy dzień dziewiętnasty rok rządów Nabuchodonozora). Posługując się językiem liczb, autor Królów sugeruje, że zniszczenie Świątyni Salomona było skutkiem grzechów Manassesa i Jeroboama II (siódmi królowie od końca w genealogiach królów Izraela i Judy), błędów Jozjasza i Szalluma (piąci królowie od końca) oraz głupoty i apostazji Jeroboama I i Abijjama (dziewiętnaści królowie od końca w genealogiach). Data zniszczenia Świątyni Salomona przekazana w Księgach Królewskich nie musi być zatem tylko skutkiem przypadkowego zniekształcenia, lecz może wynikać z koncepcji redaktora Ksiąg Królewskich ${ }^{59}$. Autor biblijny pisał Księgi Królewskie, kierując się własną koncepcją i dlatego szukanie tekstu pierwotnego Ksiąg Królewskich może być bezzasadne ${ }^{60}$.

Niniejszy artykuł rzuca nowe światło na przyczynę wielu trudności w ustaleniu dokładnych dat panowania władców w obu królestwach. Domaga się zmiany współczesnych podejść do historii starożytnego Izraela i Judy ${ }^{61}$. Krytyka tekstu dowodzi, że w czasach Drugiej Świątyni nie traktowano Ksiąg Królewskich jako kroniki we współczesnym tego słowa rozumieniu ${ }^{62}$. Podobnie można powiedzieć o Księgach

59 Także data podana w Jr 52 może mieć głębsze znaczenie: zniszczenie Świątyni Salomona w zamyśle Jeremiasza zaczęło nową epokę w dziejach Narodu Wybranego (dziesiąty dzień) spowodowaną błędami Jozjasza (piąty miesiąc) i grzechami Abijjama (dziewiętnasty rok).

60 Por. R. F. Person, The Kings - Isaiah and Kings - Jeremiah Recensions, Berlin-New York 1997 (Beihefte zur Zeitschrift für die alttestamentliche Wissenschaft, 252), https://doi. org/10.1515/9783110800845.

61 Na temat współczesnych podejść do historii starożytnego Izraela i Judy zob. A. Tobolowsky, Israelite and Judahite History in Contemporary Theoretical Approaches, „Currents in Biblical Research” 17 (2018) nr 1, s. 33-58, https://doi.org/10.1177/1476993X18765117; Z. Zevit, Three Debates about Bible and Archaeology, „Biblica” 83 (2002) nr 1, s. 1-27, https://doi.org/10.2143/BIB.83.1.3200291.

62 J. Trebolle Barrera, Textual and Literary Criticism of the Books of Kings. Collected Essays, Leiden 2020 (Vetus Testamentum Supplements, 185), https://doi.org/10.1163/ 9789004426016 . 
Kronik $^{63}$. Pismo Święte nie jest podręcznikiem historii, lecz pismem natchnionym ${ }^{64}$. Biblijna historia epoki królewskiej Izraela i Judy przedstawiona w Księgach Samuela i Królewskich nie jest faktograficznym przedstawieniem epoki królewskiej Narodu Wybranego, lecz dziełem autora biblijnego, efektem jego teologicznej koncepcji. W narracji biblijnej można jednak odnaleźć wiele historycznych danych pozwalających odtworzyć epokę królewską, dlatego należy podjąć dalsze badania z uwzględnieniem powyższych spostrzeżeń.

\section{Abstrakt}

\section{Kilka spostrzeżeń dotyczących genealogii królów izraelskich i judzkich}

Genealogia królów Izraela i Judy (dynastii Dawidowej) jest wynikiem zamierzonej kompozycji autora biblijnego. Królowie mieli być przeciwieństwami patriarchów. Szczególne znaczenie mieli Henoch, siódmy patriarcha, i Noe, dziesiąty patriarcha. Pierwszy był sprawiedliwy i dlatego został wzięty do nieba; drugi uratował rodzaj ludzki w czasie potopu. Manasses i Jeroboam II byli niegodziwi, są więc przeciwieństwem Henocha i dlatego zostali umieszczeni na siódmym miejscu od końca w wykazie królów. Jehu i Jotam uratowali odpowiednio Izrael i Judę, są więc antytypami Noego i dlatego zostali umieszczeni na dziesiątym miejscu od końca w listach królów. Co więcej, ze względu na liczbę patriarchów genealogie królów izraelskich i judzkich miały liczyć 22 władców każda. Niektórzy królowie mogli więc zostać dodani lub opuszczeni. Dlatego genealogia władców nie odzwierciedla rzeczywistej sukcesji. To jest główna przyczyna wielu trudności w ustaleniu chronologii królów Izraela i Judy.

Słowa kluczowe: chronologia, dynastia, Izrael, Juda, król

63 Por. R. W. Klein, New Evidence For an Old Recension of Reigns, „Harvard Theological Review” 60 (1967) nr 1, s. 93-105, https://doi.org/10.1017/S0017816000028947; L. C. Allen, Further Thoughts on an Old Recension of Reigns in Paralipomena, „Harvard Theological Review” 61 (1968) nr 3, s. 483-491, https://doi.org/10.1017/S001781600002928X; Ralph W. Klein, Supplements in the Paralipomena: A Rejoinder, „Harvard Theological Review” 61 (1968) nr 3, s. 492-495, https://doi.org/10.1017/S0017816000029291.

64 Por. M. Majewski, Prawda historyczna Pisma Świętego. Refleksja na kanwie nowego dokumentu Papieskiej Komisji Biblijnej, „Ruch Biblijny i Liturgiczny” 68 (2015) nr 3, s. 237-264, https://doi.org/10.21906/rbl.20; H. Witczyk, Prawda Pisma Świętego jako owoc natchnienia, „Ruch Biblijny i Liturgiczny” 68 (2015) nr 2, s. 101-124, https://doi.org/10.21906/rbl.13. 


\section{Abstract}

\section{Several Observations Regarding the Genealogy of the Kings of Israel and Judah}

The genealogy of the kings of Israel and Judah (the Davidic dynasty) is the result of the Biblical author's intended compositions. These kings were supposed to be juxtaposed with the patriarchs. Particularly important were Enoch, the seventh patriarch, and Noah, the tenth patriarch. The former was righteous and thus was summoned to heaven, while the latter saved humankind during the Great Flood. Manasseh and Jeroboam II were ignoble; thus, they are the opposite of Enoch and thus they were situated in the seventh to last place in the list of kings. Jehu and Gotham saved Israel and Judah, respectively; thus, they are the antithesis of Noah and thus they were situated in tenth to last place in the list of kings. Furthermore, due to the number of patriarchs the genealogies of the kings of Israel and Judah each had twenty-two rulers. Thus, the genealogy of the rulers does not reflect the true succession. This is the main cause of numerous difficulties in establishing the chronology of the kings of Israel and Judah.

Keywords: chronology, dynasty, Israel, Judah, king

\section{References}

Abadie, P. (2003). From the Impious Manasseh (2 Kings 21) to the Convert Manasseh (2 Chronicles 33). Theological Rewriting by the Chronicler. In R. W. Klein, M. P. Graham, S. L. McKenzie, \& G. N. Knoppers (Eds.), The Chronicler as Theologian. Essays in Honor of Ralph W. Klein (pp. 89-104). T \& T Clark International.

Albright, W. F. (1945). The Chronology of the Divided Monarchy of Israel. Bulletin of the American Schools of Oriental Research, 100, 16-22. https://doi.org/10.2307/1355182

Allen, L. C. (1968). Further Thoughts on an Old Recension of Reigns in Paralipomena. Harvard Theological Review, 61(3), 483-491. https://doi.org/10.1017/S001781600002928X

Alt, A., Kittel, R., Bardtke, H., Rüger, H. P., Ziegler, J., Elliger, K., Rudolph, W., Weil, G. E., Schenker, A. (1997). Biblia Hebraica Stuttgartensia (5th ed.). Deutsche Bibelgesellschaft.

Andersen, K. T. (1969). Die chronologie der Könige von Israel und Juda. Studia Theologica. Nordic Journal of Theology, 23(1), 69-114. https://doi.org/10.1080/00393386908599903 Andersen, Knud Tage. (1989). Noch einmal: Die Chronologie der Könige von Israel und Juda. Scandinavian Journal of the Old Testament, 3(1), 1-45. https://doi. org/10.1080/09018328908584908

Arie, E. (2008). Reconsidering the Iron Age II Strata at Tel Dan: Archaeological and Historical Implications. Tel Aviv, 35(1), 6-64. https://doi.org/10.1179/tav.2008.2008.1.6 
Ash, P. S. (1998). Jeroboam I and the Deuteronomistic Historian's Ideology of the Founder. The Catholic Biblical Quarterly, 60(1), 16-24.

Avioz, M. (2003). When Was the First Temple Destroyed, According to the Bible? Biblica, 84(4), 562-565. https://doi.org/10.2143/BIB.84.4.3194492

Avioz, M. (2005). The Book of Kings in Recent Research (Part I). Currents in Biblical Research, 4(1), 11-55. https://doi.org/10.1177/1476993X05055585

Avioz, M. (2006). The Book of Kings in Recent Research (Part II). Currents in Biblical Research, 5(1), 11-57. https://doi.org/10.1177/1476993X06068698

Ball, E. (1977). The Co-Regency of David and Solomon (1 Kings I). Vetus Testamentum, 27(3), 268-279. https://doi.org/10.1163/156853377X00168

Barnes, W. H. (2018). Studies in the Chronology of the Divided Monarchy of Israel. Brill. https:// doi.org/10.1163/9789004369573

Barrick, W. B. (2001). Another Shaking Of Jehoshaphat's Family Tree. Jehoram And Ahaziah Once Again. Vetus Testamentum, 51(1), 9-25.https://doi.org/10.1163/156853301300102174

Baruchi-Unna, A. (2017). Jehuites, Ahabites, and Omrides: Blood Kinship and Bloodshed. Journal for the Study of the Old Testament, 42(1), 3-21. https://doi.org/10.1177/ 0309089216661177

Beentjes, P. C. (2008). Tradition and Transformation in the Book of Chronicles. Brill. https:// doi.org/10.1163/ej.9789004170445.i-214

Begg, C. (1988). The Death of Josiah. Ephemerides Theologicae Lovanienses, 64(1), 157-163. https://doi.org/10.2143/ETL.64.1.556378

Begg, C. (1996). Jotham and Amon: Two Minor Kings of Judah According to Josephus. Bulletin for Biblical Research, 6, 1-13.

Begg, C. T. (1986). The Significance of Jehoiachin's Release: A New Proposal. Journal for the Study of the Old Testament, 11(36), 49-56. https://doi.org/10.1177/030908928601103604

Begg, C. T. (1987). The Death of Josiah in Chronicles: Another View. Vetus Testamentum, 37(1-4), 1-8. https://doi.org/10.1163/156853387X00013

Begrich, J. (1929a). Der Syrisch-Ephraimitische Krieg und seine weltpolitischen Zusammenhänge. Zeitschrift Der Deutschen Morgenländischen Gesellschaft, 83(3-4), 213-237.

Begrich, J. (1929b). Die Chronologie der Könige von Israel und Juda. Und die Quellen des Rahmens der Königsbücher. J. C. B. Mohr.

Benner, J. A. (2004). The ancient Hebrew language and alphabet. Understanding the ancient Hebrew language of the Bible based on ancient Hebrew culture and thought. Virtualbookworm.com Pub.

Biblia Hebraica Leningradensia. Prepared according to the vocalization accents, and masora of Aaron ben Moses ben Asher in the Leningrad Codex. (2000). Hendrickson Publishers. Bickert, R. (1987). König Ahas und der Prophet Jesaja. Ein Beitrag zum Problem des syrisch-ephraimitischen Krieges. Zeitschrift Für Die Alttestamentliche Wissenschaft, 99(3), 361-384. https://doi.org/10.1515/zatw.1987.99.3.361 
Bodner, K. (2019). The Theology of the Book of Kings. Cambridge University Press. https:// doi.org/10.1017/9781316414910

Brzegowy, T. (1998). Chronologia epoki królewskiej w starożytnym Izraelu. Ruch Biblijny i Liturgiczny, 51(4), 261-270. https://doi.org/10.21906/rbl.697

Chrostowski, W. (1996). Ogród Eden. Zapoznane swiadectwo asyryjskiej diaspory. Vocatio. Chrostowski, W. (2003). Asyryjska diaspora Izraelitów i inne studia. Vocatio.

Chrostowski, W. (2017). Asyryjska diaspora Izraelitów jako wyzwanie dla biblistyki i asyriologii. Collectanea Theologica, 86(3), 5-26. https://doi.org/10.21697/ct.2016.86.3.01

Chrostowski, W. (2019). Konflikt wokół odbudowy świątyni (Ezd 4, 1-5). Przyczynek do transformacji religii biblijnego Izraela i narodzin judaizmu. Collectanea Theologica, 89(3), 43-84. https://doi.org/10.21697/ct.2019.89.3.02

Chrostowski, W. (2020). Kronikarskie dzieło historyczne jako projekt nowej przyszłości Izraela. Collectanea Theologica, 89(4), 7-46. https://doi.org/10.21697/ct.2019.89.4.01

Clark, W. M. (1971). The Righteousness of Noah. Vetus Testamentum, 21(3), 261-280. https:// doi.org/10.1163/156853371X00407

Cohn, R. L. (1985). Literary Technique in the Jeroboam Narrative. Zeitschrift Für Die Alttestamentliche Wissenschaft, 97(1), 23-35. https://doi.org/10.1515/zatw.1985.97.1.23

Cranz, I. (2019). The motif of Uzziah's תערצ in the Deuteronomistic History, Chronicles, and beyond. Journal for the Study of the Old Testament, 44(2), 233-249. https://doi. org/10.1177/0309089218755558

Dalley, S. (2004). Recent Evidence from Assyrian Sources for Judaean History from Uzziah to Manasseh. Journal for the Study of the Old Testament, 28(4), 387-401. https://doi. org/10.1177/030908920402800401

Davis, A. R. (2013). Tel Dan in Its Northern Cultic Context. Society of Biblical Literature. https://doi.org/10.2307/j.ctt5vjz66

Davis, A. R. (2019). Reconstructing the Temple. The Royal Rhetoric of Temple Renovation in the Ancient Near East and Israel. Oxford University Press.

Deboys, D. G. (1990). History and Theology in the Chronicler's Portrayal of Abijah. Biblica, 71(1), 48-62. https://doi.org/10.2143/BIB.71.1.3217747

Debus, J. (1968). Die Sünde Jerobeams. Vandenhoeck \& Ruprecht. https://doi.org/10.13109/ 9783666531996

Delamarter, S. (2004). The Death of Josiah in Scripture and Tradition: Wrestling with the Problem of Evil? Vetus Testamentum, 54(1), 29-60. https://doi.org/10.1163/ 156853304772932924

Dubovský, P. (2006). Tiglath-pileser III’s Campaigns in 734-732 B.C. Historical Background of Isa 7; 2 Kgs 15-16 and 2 Chr 27-28. Biblica, 87(2), 153-170. https://doi.org/10.2143/ BIB.87.2.3189037

Duke, R. K. (2009). Recent Research in Chronicles. Currents in Biblical Research, 8(1), 10-50. https://doi.org/10.1177/1476993X09338966 
Dziadosz, D. (2020). Między historią, ideologią i teologią. Pro-Dawidowa lektura tradycji o Saulu w Pierwszej Księdze Kronik. Collectanea Theologica, 89(4), 47-93. https://doi. org/10.21697/ct.2019.89.4.02

Ehrlich, C. S. (1991). Coalition Politics in Eighth Century B.C.E. Palestine. The Philistines and the Syro-Ephraimite War. Zeitschrift Des Deutschen Palästina-Vereins, 107, 48-58.

Etz, D. V. (1996). The Genealogical Relationships of Jehoram and Ahaziah, and of Ahaz and Hezekiah, Kings of Judah. Journal for the Study of the Old Testament, 21(71), 39-53. https://doi.org/10.1177/030908929602107104

Finkelstein, I. (2008). The Settlement History of Jerusalem in the Eighth and Seventh Centuries BC. Revue Biblique, 115(4), 499-515. https://doi.org/10.2143/RBI.115.4.3206463

Finkelstein, I. (2011). Stages in the Territorial Expansion of the Northern Kingdom. Vetus Testamentum, 61(2), 227-242. https://doi.org/10.1163/156853311X571437

Finkelstein, I. (2020). Jeroboam II's Temples. Zeitschrift Für Die Alttestamentliche Wissenschaft, 132(2), 250-265. https://doi.org/10.1515/zaw-2020-2004

Flis, J. (2004). Konkordancja Starego i Nowego Testamentu do Biblii Tysiaclecia (4th ed.). Vocatio.

Frost, S. B. (1968). The Death of Josiah. A Conspiracy of Silence. Journal of Biblical Literature, 87(4), 369-382. https://doi.org/10.2307/3263298

Galil, G. (1991). The Babylonian Calendar and the Chronology of the Last Kings of Judah. Biblica, 72(3), 367-378.

Galil, G. (1996). The chronology of the kings of Israel and Judah. E. J. Brill.

Galil, Gershon. (2000). A New Look at the Inscriptions of Tiglath-pileser III. Biblica, 81(4), 511-520. https://doi.org/10.2143/BIB.81.4.3200456

Garcia-Treto, F. O. (1990). The Fall of the House: A Carnivalesque Reading of 2 Kings 9 and 10. Journal for the Study of the Old Testament, 15(46), 47-65. https://doi. org/10.1177/030908929001504605

Gelander, S. (2011). From Two Kingdoms To One Nation - Israel and Judah: Studies in Division and Unification. Brill. https://doi.org/10.1163/ej.9789004203464.i-260

Geobey, R. (2016). The Jeroboam Story in the (Re)Formulation of Israelite Identity: Evaluating the Literary-Ideological Purposes of 1 Kings 11-14. Journal of Hebrew Scriptures, 16, 1-42. https://doi.org/10.5508/jhs.2016.v16.a2

Gomes, J. F. (2012). The Sanctuary of Bethel and the Configuration of Israelite Identity. De Gruyter. https://doi.org/10.1515/9783110925180

Grabbe, L. L. (2017). Jeroboam I? Jeroboam II? Or Jeroboam 0? Jeroboam in History and Tradition. In O. Lipschitz, Y. Gadot, \& M. Adams (Eds.), Rethinking Israel. Studies in the history and archaeology of ancient Israel in honor of Israel Finkelstein (pp. 115-124). Eisenbrauns.

Green, A. R. (1982). The Chronology of the Last Days of Judah: Two Apparent Discrepancies. Journal of Biblical Literature, 101(1), 57-73. https://doi.org/10.2307/3260440

Greer, J. S. (2013). Dinner at Dan. Biblical and Archaeological Evidence for Sacred Feasts at Iron Age II Tel Dan and Their Significance. Brill. https://doi.org/10.1163/9789004260627 
Halpern, B. (1998). Why Manasseh is blamed for the Babylonian exile: The evolution of a biblical tradition. Vetus Testamentum, 48(4), 473-514. https://doi.org/10.1163/ 156853398774228417

Hänsler, H. (1929a). Die biblische Chronologie des 8. Jahrhunderts v. Chr. Ein Lösungsversuch der Schwierigkeiten in der Zeitrechnung der hl. Schrift. Biblica, 10(3), 257-274.

Hänsler, H. (1929b). Die biblische Chronologie des 8. Jahrhunderts v. Chr. Ein Lösungsversuch der Schwierigkeiten in der Zeitrechnung der hl. Schrift (Cont.). Biblica, 10(4), 377-393.

Haran, M. (1967). The Rise and Decline of the Empire of Jeroboam Ben Joash. Vetus Testamentum, 17(3), 266-297. https://doi.org/10.1163/156853367X00024

Hartman, T. C. (1972). Some Thoughts on the Sumerian King List and Genesis 5 and 11B. Journal of Biblical Literature, 91(1), 25-32. https://doi.org/10.2307/3262917

Hasegawa, S., Levin, C., Radner, K., \& McKenzie, S. L. (Eds.). (2018). The Last Days of Israel:

Chronological Considerations. In The Last Days of the Kingdom of Israel (pp. 289-300).

De Gruyter. https://doi.org/10.1515/9783110566604-014

Hayes, J. H., \& Kuan, J. K. (1991). The Final Years of Samaria (730-720 BC). Biblica, 72(2), 153-181. https://doi.org/10.2143/BIB.72.2.3217713

Hayes, John Haralson, \& Hooker, P. K. (1988). A new chronology for the kings of Israel and Judah and its implications for Biblical history and literature. John Knox Press.

Hendel, R. S. (1998). The text of Genesis 1-11. Textual studies and critical edition. Oxford University Press.

Hensel, B. (2019). On the relationship of Judah and Samaria in post-exilic times. A farewell to the conflict paradigm. Journal for the Study of the Old Testament, 44(1), 19-42. https:// doi.org/10.1177/0309089217748304

Herzog, Z., \& Singer-Avitz, L. (2004). Redefining the Centre. The Emergence of State in Judah. Tel Aviv, 31(2), 209-244. https://doi.org/10.1179/tav.2004.2004.2.209

Hөyrup, J. (1993). “Remarkable Numbers” in Old Babylonian Mathematical Texts. A Note on the Psychology of Numbers. Journal of Near Eastern Studies, 52(4), 281-286. https:// doi.org/10.1086/373636

Hubler, C. (2020). 'No longer will you call me "my Ba'al”': Hosea's polemic and the semantics of 'Ba'al' in 8th century B.C.E. Israel. Journal for the Study of the Old Testament. https://doi.org/ 10.1177/0309089219862804

Hull, J. H. (2017). King Lists as a Structuring Principle in the Book of Kings. In S. L. Birdsong \& S. Frolov (Eds.), Partners with God: Theological and Critical Readings of the Bible in Honor of Marvin A. Sweeney (Vol. 2, pp. 133-146). Claremont Press.

Irvine, S. A. (1990). Isaiah, Ahaz, and the syro-ephraimitic crisis. Scholars Press.

Jacobus, H. R. (2009). The Curse of Cainan (Jub. 8.1-5): Genealogies in Genesis 5 and Genesis 11 and a Mathematical Pattern. Journal for the Study of the Pseudepigrapha, 18(3), 207-232. https://doi.org/10.1177/0951820709103182 
Janzen, D. (2008). An Ambiguous Ending: Dynastic Punishment in Kings and the Fate of the Davidides in 2 Kings 25.27-30. Journal for the Study of the Old Testament, 33(1), 39-58. https://doi.org/10.1177/0309089208094459

Janzen, D. (2013). The Sins of Josiah and Hezekiah. A Synchronic Reading of the Final Chapters of Kings. Journal for the Study of the Old Testament, 37(3), 349-370. https:// doi.org/10.1177/0309089213475396

Jensen, M. D. (2015). Noah, the Eighth Proclaimer of Righteousness: Understanding 2 Peter 2.5 in Light of Genesis 4.26. Journal for the Study of the New Testament, 37(4), 458-469. https://doi.org/10.1177/0142064X15581322

Jepsen, A. (1968). Noch Einmal Zur Israelitisch-Jüdischen Chronologie. Vetus Testamentum, 18(1-4), 31-46. https://doi.org/10.1163/156853368X00032

Jepsen, A., \& Hanhart, R. (1964). Untersuchungen zur israelitisch-jüdischen Chronologie. A. Töpelmann.

Jeung Yeoul Bang. (2017). The Canonical Function of Psalms 19 and 119 as a MacroTorah Frame. The Korean Journal of Old Testament Studies, 23(4), 251-285. https://doi. org/10.24333/JKOTS.2017.23.4.251

Jones, G. H. (1994). From Abijam to Abijah. Zeitschrift Für Die Alttestamentliche Wissenschaft, 106(3), 420-434. https://doi.org/10.1515/zatw.1994.106.3.420

Jonker, L. (2007). Reforming History. The Hermeneutical Significance of the Books of Chronicles. Vetus Testamentum, 57(1), 21-44. https://doi.org/10.1163/156853307X167846

Kalimi, I. (2004). The reshaping of ancient Israelite history in Chronicles. Eisenbrauns.

Kalimi, I. (2012). Kings with Privilege. The Core Source(s) of the Parallel Texts between the Deuteronomistic and Chronistic. Revue Biblique, 119(4), 498-517. https://doi. org/10.2143/RBI.119.4.3203549

Kaminski, C. M. (2014). Was Noah Good? Finding Favour in the Flood Narrative. Bloomsbury T \& T Clark. https://doi.org/10.5040/9780567659026

Kelle, B. E. (2005). Hosea 2. Metaphor and rhetoric in historical perspective. Society of Biblical Literature.

Keulen, P. S. F. van, \& Moor, J. C. de. (1996). Manasseh through the eyes of the deuteronomists. The Manasseh account (2 Kings 21:1-18) and the final chapters of the deuteronomistic history. Brill.

Killebrew, A. E., \& Vaughn, A. G. (2003). Jerusalem in Bible and archaeology. The First Temple period. Society of Biblical Literature.

King, A. M. (2017). Did Jehu Destroy Baal from Israel? A Contextual Reading of Jehu's Revolt. Bulletin for Biblical Research, 27(3), 309-332.

Kinowski, K. (2019). Reinterpretacja historii w Księgach Kronik. Przypadek króla Manassesa. Collectanea Theologica, 89(4), 139-168. https://doi.org/10.21697/ct.2019.89.4.05

Klein, R. W. (1967). New Evidence For an Old Recension of Reigns. Harvard Theological Review, 60(1), 93-105. https://doi.org/10.1017/S0017816000028947 
Klein, R. W. (1968). Supplements in the Paralipomena: A Rejoinder. Harvard Theological Review, 61(3), 492-495. https://doi.org/10.1017/S0017816000029291

Klein, R. W. (1983). Abijah's Campaign Against the North (II Chr 13) - What Were the Chronicler's Sources? Zeitschrift Für Die Alttestamentliche Wissenschaft, 95(2), 210-217. https://doi.org/10.1515/zatw.1983.95.2.210

Knauf, E. A. (2017). Jeroboam ben Nimshi: The Biblical Evidence. Hebrew Bible and Ancient Israel, 6(3), 290-307. https://doi.org/10.1628/219222717X15162808430766

Knoppers, G. (2011). Saint or Sinner? Manasseh in Chronicles. In J. Corley \& H. van Grol (Eds.), Rewriting Biblical History (pp. 211-230). De Gruyter. https://doi.org/10.1515/ 9783110240948.211

Knoppers, G. N. (1993). Two Nations Under God: The Deuteronomistic History of Solomon and the Dual Monarchies: Vol. 1: The Reign of Solomon and the Rise of Jeroboam. Brill. https://doi.org/10.1163/9789004369689

Knoppers, G. N. (2010). Theories of the Redaction(s) of Kings. In B. Halpern \& A. Lemaire (Eds.), The Books of Kings (pp. 67-88). Brill. https://doi.org/10.1163/ej.9789004177291.i-712.23

Kuan, J. K. (2016). Neo-Assyrian historical inscriptions and Syria-Palestine Israelite/JudeanTyrian-Damascene political and commercial relations in the ninth-eighth centuries $B C E$. Wipf \& Stock.

Kucharek, D. (2019). Manasses jako nawrócony król - poszukiwanie przyczyn zmiany punktu widzenia autora 2 Krn 33,1-20. Warszawskie Studia Teologiczne, 32(2), 66-83. Laato, A. (1986). New Viewpoints on the Chronology of the Kings of Judah and Israel. Zeitschrift Für Die Alttestamentliche Wissenschaft, 98(2), 210-221. https://doi.org/10.1515/ zatw.1986.98.2.210

Laato, A. (1992). Josiah and David redivivus. The historical Josiah and the Messianic expectations of exilic and postexilic times. Almqvist \& Wiksell International.

Lamb, D. T. (2007). Righteous Jehu and his Evil Heirs. The Deuteronomist's Negative Perspective on Dynastic Succession. Oxford University Press.

Larsson, G. (2002). The Chronology of the Kings of Israel and Judah as a System. Zeitschrift für die alttestamentliche Wissenschaft, 114(2), 224-235. https://doi.org/10.1515/ zatw.2002.012

Lemke, W. E. (1965). The Synoptic Problem in the Chronicler's History. Harvard Theological Review, 58(4), 349-363. https://doi.org/10.1017/S0017816000002583

Lenzi, A. (2010). The Metonic Cycle, Number Symbolism, and the Placement of Psalms 19 and 119 in the MT Psalter. Journal for the Study of the Old Testament, 34(4), 447-473. https://doi.org/10.1177/0309089210372847

Leuchter, M. (2006). Jeroboam the Ephratite. Journal of Biblical Literature, 125(1), 51-72. https://doi.org/10.2307/27638346

Levenson, J. D. (1984). The Last Four Verses in Kings. Journal of Biblical Literature, 103(3), 353-361. https://doi.org/10.2307/3260777 
Levin, C. (2011). Das synchronistische Exzerpt aus den Annalen der Könige von Israel und Juda. Vetus Testamentum, 61(4), 616-628. https://doi.org/10.1163/156853311X560772

Lewis, J. P. (1978). A study of the interpretation of Noah and the flood in Jewish and Christian literature. E. J. Brill.

Lewy, J. (1927). Die Chronologie der Könige von Israel und Juda. De Gruyter. https://doi. org/10.1515/9783111551203

Majewski, M. (2015). Prawda historyczna Pisma Świętego. Refleksja na kanwie nowego dokumentu Papieskiej Komisji Biblijnej. Ruch Biblijny i Liturgiczny, 68(3), 237-264. https://doi.org/10.21906/rbl.20

Malamat, A. (1968). King Lists of the Old Babylonian Period and Biblical Genealogies. Journal of the American Oriental Society, 88(1), 163-173. https://doi.org/10.2307/597910

Mays, J. L. (1987). The Place of the Torah-Psalms in the Psalter. Journal of Biblical Literature, 106(1), 3-12. https://doi.org/10.2307/3260550

McCarter, P. K. (1974). “Yaw, Son of 'Omri”: A Philological Note on Israelite Chronology. Bulletin of the American Schools of Oriental Research, 216, 5-7. https://doi.org/10.2307/1356327

Mcconville, J. G. (1989). Narrative and Meaning in the Books of Kings. Biblica, 70(1), 31-49. https://doi.org/10.2143/BIB.70.1.3217784

Miller, J. M. (1967). The Fall of the House of Ahab. Vetus Testamentum, 17(3), 307-324. https://doi.org/10.1163/156853367X00042

Mitchell, C. (2006). The Ironic Death of Josiah in 2 Chronicles. https://doi.org/10.17613/M6SC6B

Mokoena, L. L. D., \& Meyer, E. E. (2019). Jehu's violent coup and the justification of violence. HTS Teologiese Studies, 75(3), 1-6. https://doi.org/10.4102/hts.v75i3.5326

Moore, M. (2003). Jehu's Coronation and Purge of Israel. Vetus Testamentum, 53(1), 97-114. https://doi.org/10.1163/156853303321095899

Mowinckel, S. (1932). Die Chronologie der israelitischen und jüdischen Könige. E. J. Brill.

Mucha, P. M. (2019). Przyczynek do chronologii królów Izraela i Judy. Ruch Biblijny i Liturgiczny, 72(2), 131-148. https://doi.org/10.21906/rbl.3629

Mullen, E. T. (1987). The Sins of Jeroboam: A Redactional Assessments. The Catholic Biblical Quarterly, 49(2), 212-232.

Mullen, E. Theodore. (1988). The Royal Dynastic Grant to Jehu and the Structure of the Books of Kings. Journal of Biblical Literature, 107(2), 193-206. https://doi.org/10.2307/3267695

Murray, D. F. (2001). Of All the Years the Hopes: Or Fears? Jehoiachin in Babylon (2 Kings 25:27-30). Journal of Biblical Literature, 120(2), 245-265. https://doi.org/10.2307/3268294

Na'aman, N. (1993). Azariah of Judah and Jeroboam II of Israel. Vetus Testamentum, 43(2), 227-234. https://doi.org/10.1163/156853393X00061

Na'aman, N. (1995). Tiglath-pileser III’s Campaigns Against Tyre and Israel (734-732 B.C.E.). Tel Aviv, 22(2), 268-278. https://doi.org/10.1179/tav.1995.1995.2.268

Na'aman, N. (2007). When and How Did Jerusalem Become a Great City? The Rise of Jerusalem as Judah's Premier City in the Eighth-Seventh Centuries B.C.E. Bulletin 
of the American Schools of Oriental Research, 347, 21-56. https://doi.org/10.1086/ BASOR25067021

Na'aman, N. (2009). The Growth and Development of Judah and Jerusalem in the Eighth

Century BCE. Revue Biblique, 116(3), 321-335. https://doi.org/10.2143/RBI.116.3.3206430 Oded, B. (1972). The Historical Background of the Syro-Ephraimite War Reconsidered. The Catholic Biblical Quarterly, 34(2), 153-165.

Ohm, A. T. (2010). Manasseh and the Punishment Narrative. Tyndale Bulletin, 61(2), 237-254. Pakkala, J. (2008). Jeroboam without Bulls. Zeitschrift Für Die Alttestamentliche Wissenschaft, 120(4), 501-525. https://doi.org/10.1515/ZAW.2008.031

Pavlovský, V., \& Vogt, E. (1964). Die Jahre der Könige von Juda und Israel. Biblica, 45(3), 321-347.

Person, R. F. (1997). The Kings - Isaiah and Kings - Jeremiah Recensions. De Gruyter. https:// doi.org/10.1515/9783110800845

Rahlfs, A. (Ed.). (2014). Septuaginta. Id est Vetus Testamentum graece iuxta LXX interpretes. Deutsche Bibelgesellschaft.

Reinhold, G. G. G., \& Golinets, V. (2008). Die Zahl Sieben im Alten Orient: Studien zur Zahlensymbolik in der Bibel und ihrer altorientalischen Umwelt. The number seven in the ancient Near East: Studies on the numerical symbolism in the Bible and its ancient Near Eastern environment. Peter Lang.

Robker, J. M. (2012). The Jehu Revolution. A Royal Tradition of the Northern Kingdom and Its Ramifications. De Gruyter. https://doi.org/10.1515/9783110285017

Römer, T. (2017). How Jeroboam II became Jeroboam I. Hebrew Bible and Ancient Israel, 6(3), 372-382. https://doi.org/10.1628/219222717X15162808430810

Schedl, C. (1962). Textkritische Bemerkungen Zu Den Synchronismen Der Könige Von Israel Und Juda. Vetus Testamentum, 12(1), 88-119. https://doi.org/10.1163/156853362X00047 Schimmelpfennig, L. V., \& Kratz, R. G. (2019). Zahlen- und Buchstabensysteme im Dienste religiöser Bildung. Mohr Siebeck. https://doi.org/10.1628/978-3-16-158319-3

Schmid, K. (1997). Manasse und der Untergang Judas: »Golaorientierte« Theologie in den Königsbüchern? Biblica, 78(1), 87-99. https://doi.org/10.5167/uzh-23300

Schniedewind, W. M. (1993). History and Interpretation: The Religion of Ahab and Manasseh in the Book of Kings. The Catholic Biblical Quarterly, 55(4), 649-661.

Sergi, O. (2017). The United Monarchy and the Kingdom of Jeroboam II in the Story of Absalom and Sheba's Revolts (2 Samuel 15-20). Hebrew Bible and Ancient Israel, 6(3), 329-353. https://doi.org/10.1628/219222717X15162808430784

Siddall, Luis Robert. (2009). Tiglath-pileser III's Aid to Ahaz. Ancient Near Eastern Studies, 46, 93-106. https://doi.org/10.2143/ANES.46.0.2040712

Sommer, B. D. (2015). Nature, Revelation, and Grace in Psalm 19: Towards a Theological Reading of Scripture. Harvard Theological Review, 108(3), 376-401. https://doi. org/10.1017/S0017816015000243 
Stavrakopoulou, F. (2012). King Manasseh and Child Sacrifice. Biblical Distortions of Historical Realities. De Gruyter. https://doi.org/10.1515/9783110899641

Strange, J. (1975). Joram, King of Israel and Judah. Vetus Testamentum, 25(2), 191-201. https://doi.org/10.2307/1517266

Sweeney, M. A. (2001). King Josiah of Judah. Oxford University Press. https://doi.org/10.1093/ 0195133242.001 .0001

Tadmor, H. (1994). The inscriptions of Tiglath-pileser III, King of Assyria. Israel Academy of Sciences and Humanities.

Tal, A. (2016). Biblia hebraica quinta: Vol. 7: Genesis. German Bible Society.

Talshir, Z. (1996). The Three Deaths of Josiah and the Strata of Biblical Historiography (2 Kings XXIII 29-30; 2 Chronicles XXXV 20-5; 1 Esdras I 23-31). Vetus Testamentum, 46(2), 213-236. https://doi.org/10.1163/1568533962580793

Tetley, M. C. (2005). The reconstructed chronology of the Divided Kingdom (p. 1 online resource (210 p.)). Eisenbrauns.

Thiele, Edwin R. (1944). The Chronology of the Kings of Judah and Israel. Journal of Near Eastern Studies, 3(3), 137-186. https://doi.org/10.1086/370716

Thiele, Edwin R. (1974). Coregencies and Overlapping Reigns among the Hebrew Kings. Journal of Biblical Literature, 93(2), 174-200. https://doi.org/10.2307/3263092

Thiele, Edwin R. (1976). An Additional Chronological Note on "Yaw, Son of 'Omri.” Bulletin of the American Schools of Oriental Research, 222, 19-23. https://doi.org/10.2307/1356296

Thiele, Edwin Richard. (1994). The mysterious numbers of the Hebrew kings. Kregel.

Thompson, M. E. W. (1982). Situation and theology. Old Testament interpretations of SyroEphraimite War. Almond Press.

Tobola, Ł. K. (2016). Imiona królów judzkich - kilka spostrzeżeń. The Biblical Annals, 6(4), 601-610.

Tobolowsky, A. (2018). Israelite and Judahite History in Contemporary Theoretical Approaches. Currents in Biblical Research, 17(1), 33-58. https://doi.org/10.1177/1476993X18765117

Tomes, R. (1993). The Reason for the Syro-Ephraimite War. Journal for the Study of the Old Testament, 18(59), 55-71. https://doi.org/10.1177/030908929301805904

Trebolle Barrera, J. (2020). Textual and Literary Criticism of the Books of Kings. Collected Essays (A. Piquer Otero \& P. A. Torijano Morales, Eds.). Brill. https://doi.org/10.1163/ 9789004426016

Tułodziecki, T. (2004). Jeroboam I - reformator religii Izraela: Studium egzegetyczno-teologiczne $1 \mathrm{Krl}$ 11, 26-14, 20. Vocatio.

Vogelstein, M. (1945). Jeroboam II. The rise and fall of his empire.

Waard, H. de. (2020). Jeremiah 52 in the Context of the Book of Jeremiah. Brill. https://doi. org/10.1163/9789004423558

Wallace, H. N. (1986). The Oracles against the Israelite Dynasties in 1 and 2 Kings. Biblica, 67(1), 21-40. https://doi.org/10.2143/BIB.67.1.3217951 
Weingart, K. (2018). 2 Kings 15-18: A Chronological Conundrum? In S. Hasegawa, C. Levin, \& K. Radner (Eds.), The Last Days of the Kingdom of Israel (pp. 267-288). De Gruyter. https://doi.org/10.1515/9783110566604-013

Weippert, H. (1972). Die "deuteronomistischen“ Beurteilungen der Könige von Israel und Juda und das Problem der Redaktion der Königsbücher. Biblica, 53(3), 301-339.

Weippert, M. (1978). Jau(a) Mar Humrî - Joram Oder Jehu Von Israel? Vetus Testamentum, 28(1), 113-118. https://doi.org/10.1163/156853378X00356

White, M. (1994). Naboth's Vineyard and Jehu's Coup: The Legitimation of a Dynastic Extermination. Vetus Testamentum, 44(1), 66-76. https://doi.org/10.1163/ $156853394 X 00060$

White, M. C. (1997). The Elijah Legends and Jehu's Coup. Scholars Press.

Wifall, W. R. (1968). The Chronology of the Divided Monarchy of Israel. Zeitschrift für die alttestamentliche Wissenschaft, 80(3), 319-337. https://doi.org/10.1515/zatw.1968.80.3.319

Williamson, H. G. M. (1977). Israel in the Books of Chronicles. Cambridge University Press. https://doi.org/10.1017/CBO9780511557453

Williamson, H. G. M. (1982). The Death of Josiah and the Continuing Development of the Deuteronomic History. Vetus Testamentum, 32(2), 242-248. https://doi.org/10.1163/ $156853382 X 00135$

Williamson, H. G. M. (1987). Reliving the Death of Josiah: A Reply To C. T. Begg. Vetus Testamentum, 37(1-4), 9-15. https://doi.org/10.1163/156853387X00022

Witczyk, H. (1996). Historyczno-prorockie tło Dzieła Kronikarskiego. Ruch Biblijny i Liturgiczny, 49(1), 1-14. https://doi.org/10.21906/rbl.793

Witczyk, H. (2015). Prawda Pisma Świętego jako owoc natchnienia. Ruch Biblijny i Liturgiczny, 68(2), 101-124. https://doi.org/10.21906/rbl.13

Würthwein, E. (2008). Die Revolution Jehus Die Jehu-Erzählung in altisraelitischer und deuteronomistischer Sicht. Zeitschrift Für Die Alttestamentliche Wissenschaft, 120(1), 28-48. https://doi.org/10.1515/ZAW.2008.003

Young, D. W. (1988). A Mathematical Approach to Certain Dynastic Spans in the Sumerian King List. Journal of Near Eastern Studies, 47(2), 123-129. https://doi.org/10.1086/373263

Zawiszewski, E. (1968). Księgi Kronik - apologia czy historia. Ruch Biblijny i Liturgiczny, 21(4-5), 233-237. https://doi.org/10.21906/rbl.3142

Zenger, E. (1968). Die deuteronomistische Interpretation der Rehabilitierung Jojachins. Biblische Zeitschrift, 12, 16-31.

Zevit, Z. (2002). Three Debates about Bible and Archaeology. Biblica, 83(1), 1-27. https:// doi.org/10.2143/BIB.83.1.3200291

Zvi, E. B. (1991). The Account of the Reign of Manasseh in II Reg 21,1-18 and the Redactional History of the Book of Kings. Zeitschrift Für Die Alttestamentliche Wissenschaft, 103(3), 355-374. https://doi.org/10.1515/zatw.1991.103.3.355 